\title{
On the systematic and stratigraphic significance of pterosaurs from the Lower Cretaceous Yixian Formation (Jehol Group) of Liaoning, China
}

\author{
David M. Unwin ${ }^{1}$, Junchang Lü̈ ${ }^{2}$ \& Natalie N. Bakhurina ${ }^{3}$
}

With 7 figures and 4 tables

\begin{abstract}
A reassessment of the systematic relationships of pterosaurs from the Lower Cretaceous Yixian Formation of Liaoning Province, China, shows that Dendrorhynchoides should be reassigned to the Anurognathidae ("Rhamphorhynchoidea") and that Eosipterus possibly belongs within Ctenochasmatidae (Pterodactyloidea). These pterosaurs formed an integral part of a diverse community that inhabited lowland terrestrial environments in the region of northeast China in the Early Cretaceous. A new compilation of data for the Lower Cretaceous hints at a broad differentiation between pterosaurs that lived in continental habitats (anurognathids, ctenochasmatoids, dsungaripteroids) and those that frequented marine environments (ornithocheiroids). Moreover, there is evidence of further differentiation within continental habitats, between pterosaurs living in lowland and coastal regions (anurognathids, ctenochasmatoids) and those living in more inland environments (dsungaripteroids). The temporal and geographical range extensions for high rank taxa that are implied by the Yixian pterosaurs further emphasise the incompleteness and unevenness of the pterosaur fossil record and its unreliability for biostratigraphic zonation.
\end{abstract}

Key words: Pterosaur, Lower Cretaceous, Jehol Group, China, Anurognathidae, Ctenochasmatidae.

\section{Zusammenfassung}

Eine Neubewertung der systematischen Stellung der Flugsaurier von der unterkretazischen Yixian-Formation der Provinz Liaoning, China, zeigt, dass Dendrorhynchoides den Anurognathiden („Rhamphorhynchoidea“) zugeordnet werden kann und dass Eosipterus vermutlich zu den Ctenochasmatiden (Pterodactyloidea) gehört. Diese beiden Flugsaurier bilden einen integralen Bestandteil einer diversen Fauna, die in der Unteren Kreide ein terrestrisches Flachland-Ökosystem im Nordosten Chinas bewohnte. Fasst man die für die Untere Kreide verfügbaren Daten zusammen, so zeigt sich eine weitgehende Differenzierung zwischen Flugsauriern, die überwiegend in kontinentalen Ökosystemen lebten (Anurognathidae, Ctenochasmatoidea, Dsungaripteroidea) und jenen, die auch oft in marinen Bereichen auftreten (Ornithocheiroidea). Darüber hinaus gibt es auch Hinweise auf eine Differenzierung innerhalb der kontinentalen Habitate, zwischen Pterosauriern, die sich in den Ebenen und küstennahen Bereichen aufhielten (Anurognathidae, Ctenochasmatoidea) und den Bewohnern von mehr küstenfernen Ökosystemen (Dsungaripteroidea). Die von den Taxa der Yixian-Formation angezeigte Erweiterung der stratigraphischen und geographischen Reichweite für Taxa höheren Ranges unterstreichen die Unvollständigkeit und Unausgewogenheit des Fossilberichtes der Flugsaurier und seine Unzulänglichkeit für biostratigraphische Zonierungen.

Schlüsselwörter: Pterosaurier, Unter Kreide, Jehol Gruppe, China, Anurognathidae, Ctenochasmatidae.

\section{Introduction}

Pterosaurs, Mesozoic flying reptiles, have a relatively modest fossil record compared to most other vertebrate groups (Benton 1993). The record is also highly uneven: only about 30 species, from the 100 or so currently recognised (Wellnhofer 1991a), are known from relatively complete skeletons and most of these have been re- covered from just a handful of fossil lagerstätten scattered across a 140 million year interval, ranging from the Late Triassic to the end of the Cretaceous (e.g. Unwin 2000). The rest of the pterosaur fossil record consists, largely, of isolated and fragmentary remains that, with the exception of jaw fragments, are difficult to identify or assign, except at very general taxonomic levels. Thus, while much progress has been made

\footnotetext{
1 Museum für Naturkunde, Zentralinstitut der Humboldt-Universität zu Berlin, Invalidenstraße 43, D-10115 Berlin, Germany.

2 Institute of Vertebrate Palaeontology and Palaeoanthropology, Academica Sinica, 142 Xi-Zhi-Men-Wai Street, P.O. Box 643, Beijing 100044, China.

3 Department of Earth Sciences, University of Bristol, Queen's Road, Bristol BS8 1RJ, U.K. Received April 2000, accepted May 2000
} 
recently in understanding pterosaur anatomy. functional morphology and phylogeny (e.g. Padian 1988, Wellnhofer 1991a. Unwin 1999), the evolutionary history of the group remains comparatively poorly known.

The Lower Cretaceous pterosaur fossil record (Fig. 1, Tab. 1) reflects the general situation. although at a somewhat finer scale. The latter half (Aptian + Albian) of this 45 million year long interval contains three pterosaur lagerstätten, each of which has yielded a number of taxa and, in two cases (the Crato Formation and the Santana Formation), exceptionally well preserved remains associated with soft tissues (Martill \& Unwin 1989, Martill et al. 1990. Kellner 1997, Martill \& Frey 1998). By contrast. the first half of the Lower Cretaceous. the Neocomian (= Berriasian to Barremian) has a much poorer record that is dominated by fragmentary remains (Tab. 1). Until recently, relatively well preserved, associated remains had only been reported from the Tsagaantsav Svita of Western Mongolia (Bakhurina 1982, 1983. 1984, 1986. 1993), the Tugulu group of Xinjiang. China (Young 1964, 1973) and the Vectis Formation of the Isle-of-Wight. England (Hooley 1913). Now. however, a new Lower Cretaceous pterosaur locality has been found in western Liaoning Province, northeast China (Ji Shu'an et al. 1999).

The Jehol Group of western Liaoning Province consists of a thick sequence of Lower Cretaceous fluvial and lacustrine sediments. interca- lated with lavas and tuffs (see Wang et al. 1998, 1999 and refs therein). The lower part of the sequence has been assigned to the Yixian Formation while the upper part is referred to the Jiufotang Formation (Wang et al. 1998, 1999). Some workers (Ji Qiang et al. 2000) have suggested further subdivision of the Jehol Group, assigning the lower part of the Yixian Formation to a separate unit, the Chaomidianzi Formation, a proposal that we have not adopted here. The Yixian Formation has produced an exceptionally rich and well preserved Early Cretaceous terrestrial biota that includes a diverse palaeoflora, gastropods, bivalves, ostracods, conchostracans, insects, shrimps, fishes, frogs, turtles, lizards, non-avian dinosaurs, birds, mammals and pterosaurs (see Wang et al. [1998, 1999], Barrett [2000] and Chiappe et al. [1999] for principal references on the fauna and flora of this biota).

There has been considerable debate concerning the age of the Yixian Formation, with some workers supporting a Late Jurassic date while others argue for an Early Cretaceous age (see Barrett [2000] for a detailed review of this problem). Recently, Swisher et al. (1999), have provided some well founded radiometric dates of $124.6 \pm 0.1 \mathrm{Ma}$ for the Yixian Formation (see also Wang et al. 1999), which indicate that this unit is Barremian. This result is supported by the presence of taxa such as psittacosaurs and angiosperms that are currently known only from the Lower Cretaceous (Xu \& Wang 1998, Taylor

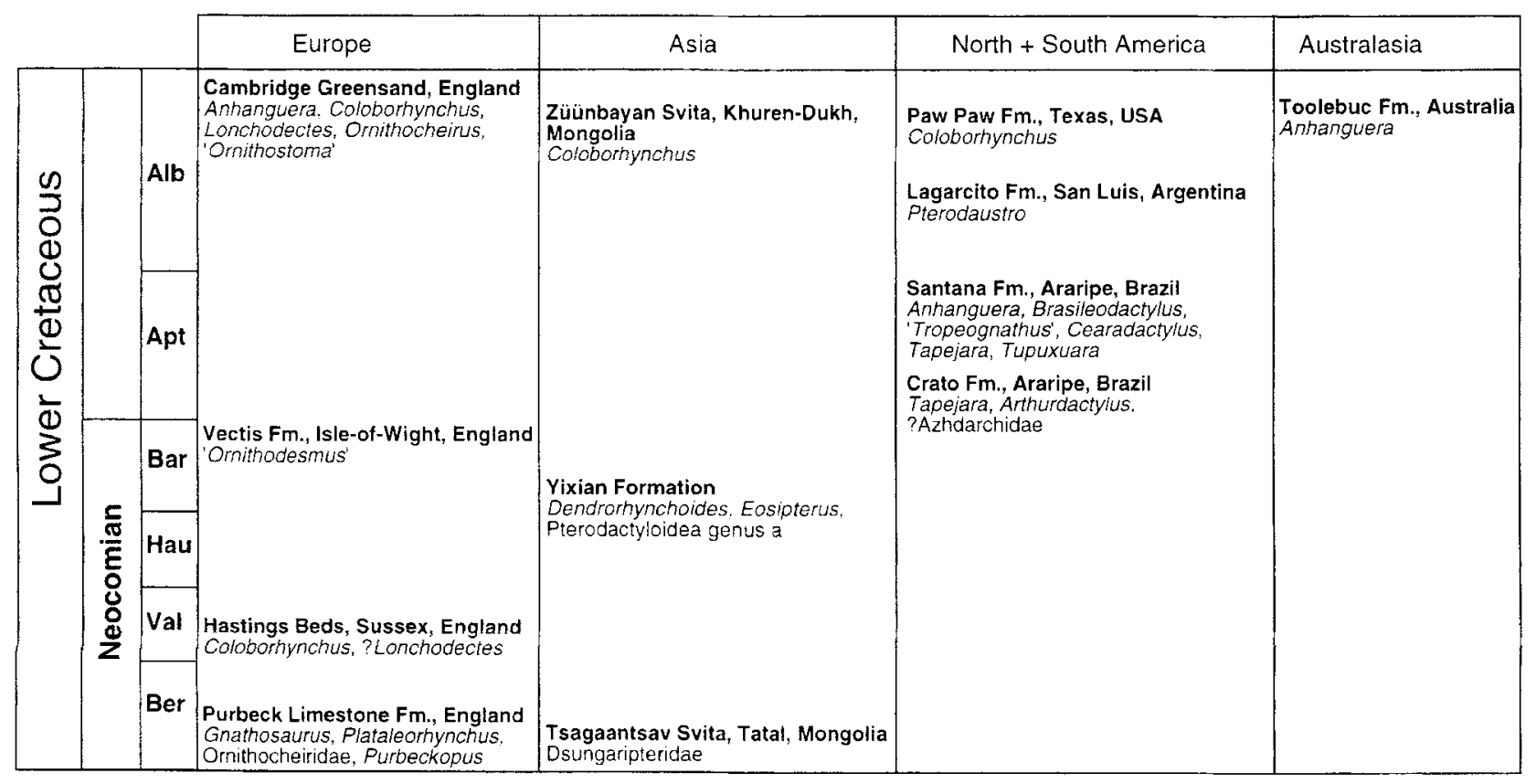

Fig. 1. Stratigraphic and geographic distribution of the main Lower Cretaceous pterosaur localities. Abbreviations: Alb, Albian; Apt. Aptian; Bar. Barremian: Ber. Berriasian; Fm. Formation; Hau. Hauterivian; Val, Valanginian 
\& Hickey 1996). Thus, for the present, we accept a late Neocomian (Barremian) age for the Yixian Formation.

Three pterosaurs have been recovered so far from the Yixian Formation (Ji \& Ji 1997, 1998, Ji Shu'an et al. 1999, Lü \& Wang 2000; Tab. 1; Figs 2, 3). The first pterosaur to be reported, Eosipterus yangi (Ji \& Ji 1997), consists of an incomplete, but partially articulated postcranial skeleton (Fig. 3). Initially, this pterosaur was identified as a pterodactyloid (Ji \& Ji 1997), but was not assigned to a particular family. More recently, a morphometric comparison led Ji Shu'an et al. (1999) to suggest that Eosipterus is probably synonymous with Pterodactylus, a pterosaur that has been reported from the Late Jurassic of East Africa and a number of localities in Western Europe (Wellnhofer 1991a), although it can only be reliably identified from the Solnhofen Limestone of Bavaria and Late Jurassic flaggy limestones of Nusplingen in Württemburg (Unwin \& Heinrich 1999, Unwin unpub. data). There are, however, two difficulties with the results of Ji Shu'an et al.'s morphometric study. First, the technique employed (Principal Components Analysis) does not distinguish between primitive and derived characters and is a phenetic, rather than a phylogenetic approach (e.g. Ridley 1986). It is possible, therefore, that the apparent similarity between Eosipterus and Pterodactylus reflects a preponderance of comparisons within the analysis that are common to many basal pterodactyloids (i.e. plesiomorphic within the Pterodactyloidea). Moreover, these plesiomorphies may be masking synapomorphies that unite Eosipterus with taxa other than Pterodactylus. A second problem with the analysis is that it includes only four pterodactyloids, all from the Late Jurassic of western Europe. It is possible that Eosipterus might be more closely related to other Jurassic pterodactyloids, or even Cretaceous taxa (as we argue below), but these potential relationships are not tested in the study by Ji Shu'an et al. (1999).

In 1998 a second pterosaur from the Yixian Formation, represented by a complete and fully articulated skeleton (Fig. 2), was described under the name Dendrorhynchus by $\mathrm{Ji}$ and $\mathrm{Ji}$, although the name was subsequently found to be preoccupied and was replaced with Dendrorhynchoides (Ji Shu'an et al. 1999). This pterosaur was identified as a "rhamphorhynchoid" (Ji \& Ji 1998), and assigned to the Rhamphorhynchidae, an important family that seems to have been present throughout much of the Jurassic (Wellnhofer 1991a). A morphometric analysis carried out by
Ji Shu'an et al. (1999) appears to support this assignment, with Dendrorhynchoides occupying a position close to, though not within, a cluster of individuals representing Rhamphorhynchus, a well known Late Jurassic pterosaur that has been reported from a number of European localities (Wellnhofer 1991a).

The assignment of Dendrorhynchoides to the Rhamphorhynchidae has recently been thrown into serious doubt, however, because it has been reported by Friend (2000) and confirmed by one of us (LJ) that the supposedly long tail of this pterosaur was not originally associated with the rest of the skeleton and consists of parts of a theropod tail that were set into the slab after its initial collection. The remaining caudal vertebrae of Dendrorhynchoides form a rather short tail, a character that does not support a close relationship with Rhamphorhynchus or other rhamphorhynchids, all of which have a long tail (Wellnhofer 1978, 1991a). In addition, the morphometric analysis suffers from the same problems as those noted for Eosipterus. It is a phenetic approach, as already mentioned, and not only does it omit all Cretaceous taxa, it also excludes a number of well known non-pterodactyloids including forms from the Late Triassic (Preondactylus, Peteinosaurus, Eudimorphodon), Early Jurassic (Dimorphodon) and even the Late Jurassic (Anurognathus and Batrachognathus).

A third specimen from the Yixian Formation, currently under study by one of us (LJ), consists of a partial skeleton associated with some soft tissue preservation (Lü \& Wang 2000). Preliminary comparisons indicate that it does not belong to either of the two taxa named and described so far.

The problems concerning the systematic relationships of the Yixian pterosaurs also bear upon the debate concerning the age of the Yixian Formation. Ji Shu'an et al. (1999) argued in favour of a Late Jurassic date for this unit on the basis of supposed similarities between the Liaoning pterosaurs and Late Jurassic forms from Europe. Other have cited their work in support of a Late Jurassic age (Chiappe et al. 1999), though Barrett (2000) has pointed out some difficulties with the assumptions underlying the use of the Yixian pterosaurs for dating.

In this paper we present the results of a reassessment of the phylogenetic relationships of Eosipterus and Dendrorhynchoides, consider the significance of these results for our understanding of pterosaur diversity and evolutionary history in the Early Cretaceous and comment on the use of pterosaurs for stratigraphic dating. The term 
"Rhamphorhynchoidea", and its derivatives, denotes a paraphyletic taxon, which is indicated herein by placing the name in double quotation marks. We prefer the more neutral term nonpterodactyloid, and restrict use of the term "Rhamphorhynchoidea" to a historic context. for example when referring to opinions published in earlier works. Where there is some doubt regarding the validity of a taxonomic name this is shown by enclosing it in single quotation marks. except in the case of 'Ornithodesmus'. which is a valid taxon awaiting a replacement name (Howse \& Milner 1993).

\section{Institutional abbreviations}

BSP, Bayerische Staatssammlung für Paläontologie und historische Geologie, Munich. Germany: CM. Camegie Museum of Natural History, Pittsburgh. USA: FHSM. Fort Hays State Museum (= Sternberg Memorial Museum). Fort Havs State University, Hays. Kansas. USA: GMV. National Geological Museum of China. Beijing. China: GSM. Geological Survey Museum. Keyworth. England: GPIB. Geologisch-Paläontologisches Institut der Universität Bonn. Germany: GPIH, Geologisch-Paläontologisches Institut der Universität Heidelberg, Germany: IMCF, Iwaki Coal and Fossil Museum Iwaki, Japan: IVPP. Institute of Vertebrate Paleontology and Paleoanthropology. Beijing. China: MB. Museum für Natur kunde, Berlin. Germany; MCSNB. Museo Civico di Storia Naturale, Bergamo. Italy: MFSN. Museo Friulano di Storia Naturale. Udine. Italy: MNHN. Museum National d Histoire Naturelle, Paris, France: MT. Institut und Museum für Geologie und Paläontologie der Universität Tübingen. Germany: NSM. National Science Museum. Tokyo. Japan: PIN. Palaeontological Institute. Russian Academy of Sciences. Moscow, Russia; PVL. Paleontología de Vertebrados. InstitutoFundación Miguel Lillo. Universidad Nacional de Tucumán. Argentina; SMF. Natur-Museum und Forschungsinstitut Senckenberg. Frankfurt am Main. Germany: SMK. Staatliches Museum für Naturkunde. Karlsruhe. Germany: SMNS. Staatliches Museum für Naturkunde. Stuttgart. Germany: TM, Teyler Museum. Haarlem. Holland: TMM. Texas Memorial Museum. Austin. Texas. USA: UB. Katedra Geologie a Paleontologie. University of Brunn. Czech Republic: UNSM. University of Nebraska State Museum. Lincoln. Nebraska. USA: ZMNH. Zhejiang Museum of Natural History. Hangzhou. Zhejiang Province. China

\section{Systematic review}

\section{Pterosauria Kaup, 1834}

"Rhamphorhynchoidea" Plieninger, 1901

Anurognathidae Kuhn, 1937

Dendrorhynchoides (= Dendrorhynchus Ji \& Ji, 1998 [preoccupied]) Ji, Ji \& Padian 1999 Dendrorhynchoides curvidentatus (Ji \& Ji, 1998)

Fig. 2

This taxon is represented by a single specimen (GMV 2128) collected from the Yixian Formation at the locality of Zhangjiagou (Wang et al.
1999) in the Sihetun region, south of Beipiao City, in western Liaoning Province, China ( $\mathrm{Ji} \&$ Ji 1998). The skeleton (Fig. 2) appears to have been complete and almost fully articulated, though parts of some elements, such as the right femur and right tibia, do not seem to be preserved on the main slab. The skull is somewhat disarticulated. possibly as a result of displacement of bones during compaction of this three dimensional structure. Similarly, the bones of the pectoral girdle also appear to have undergone some displacement. The preservation of the skeleton, and its current disposition, is remarkably similar to that observed in specimens from other pterosaur lagerstätten, most notably Rhamphorhynchus from the Solnhofen Limestone (e.g. Wellnhofer 1975a: pl. 35, fig. 1) and Sordes from the Karabastau Formation (e.g. Sharov 1971: pl. 4).

A general description of the skeleton, principal measurements and figures of the specimen have been given by Ji \& Ji (1998). An illustration of the skeleton, indicating the principal elements, including some of the skull bones, is shown in Figure 2. Dendrorhynchoides curvidentatus was a relatively small pterosaur with an estimated wing span of between 0.4 and $0.5 \mathrm{~m}$.

A problematic aspect of GMV 2128 is the tail. The basal section, which is clearly preserved in contact with the sacrum, consists of six, short, stubby, naturally articulated caudals ( $\mathrm{Ji} \& \mathrm{Ji}$ 1998). The third to sixth caudals are of similar size. but a little shorter and a little narrower than the first and second caudals. This section is followed by a short gap, then a series of long, slender caudals that are wrapped in a sheath of highly elongate zygapophyses and chevrons (Ji \& Ji 1998: fig. 1). Recently, however, Zhou, quoted in Friend (2000), has suggested that the section consisting of the elongate caudals was added subsequent to the fossil discovery and does not belong to $D$. curvidentatus. If this is correct then, originally. D. curvidentatus had a short, slightly tapering tail about $15-20 \mathrm{~mm}$ long and consisting of at least six and possibly up to eight small caudals that formed a pygostyle-like structure, as found in anurognathids and pterodactyloids.

We agree with Zhou for the following reasons: (1) in all long-tailed pterosaurs early caudals do not show a decline in size caudally, but are either of similar dimensions, or show a slight size increase (Wellnhofer 1978, 1991a). Moreover, by the fifth or sixth caudal the marked elongation typical of later vertebrae is clearly evident and the sixth caudal is usually at least twice as long as it is wide. By contrast, in D. curvidentatus the 


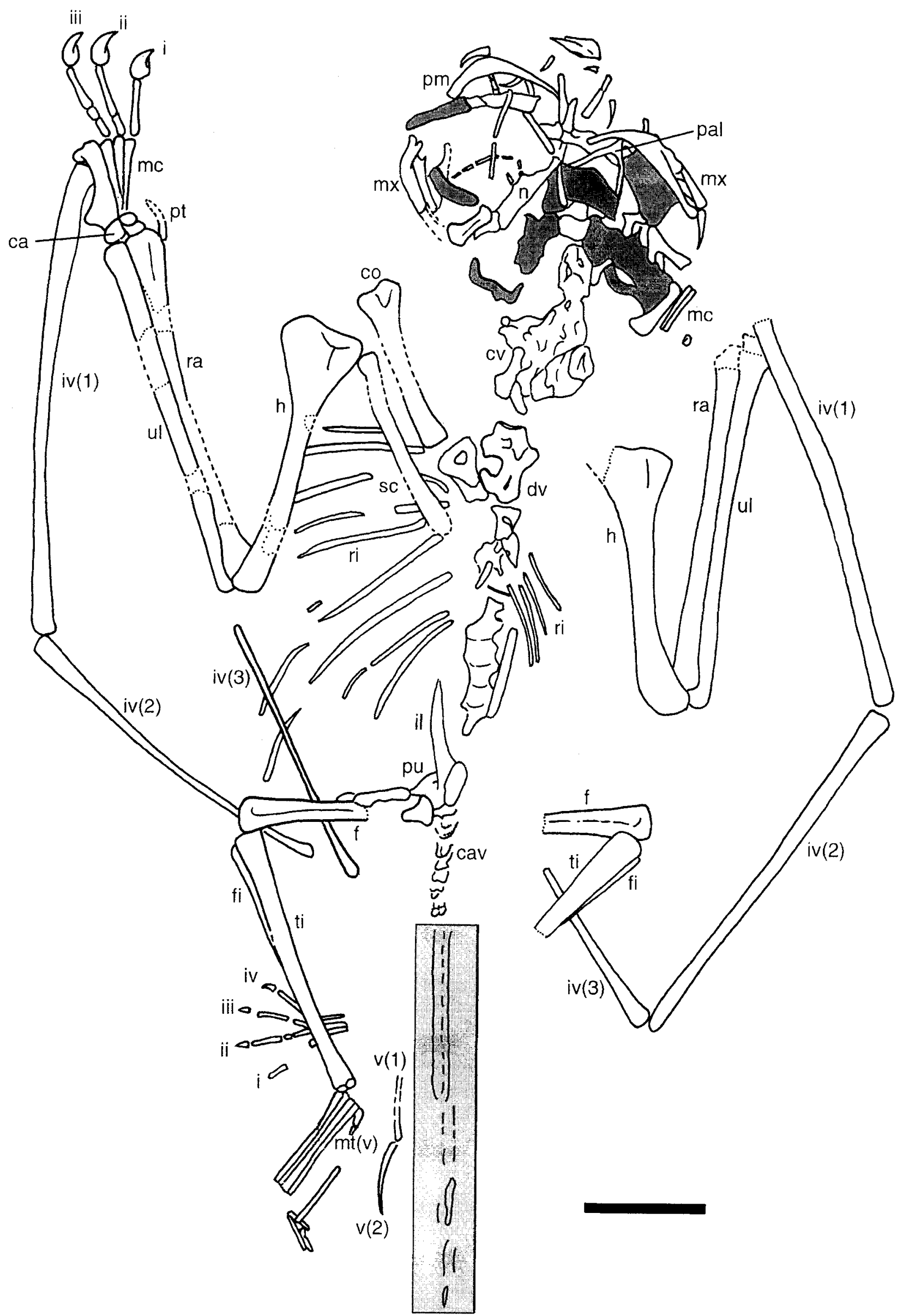


early caudals exhibit a decrease in size and the fifth and sixth elements are short and stubby. (2) An individual involved in the collection and preparation of GMV 2128 admitted to Wang Xiaolin (see Wang et al. 1999) that the elongate section of the tail had been added to the fossil subsequent to its discovery. As Chiappe et al. (1999) note, forgery has also been detected in a number of other fossils collected from the Yixian Formation.

Dendrorhynchoides is undoubtedly a member of the Pterosauria as it shows eight unambiguous apomorphies of this taxon:

(1) coracoid elongate and at least $0.75 \times$ length of scapula;

(2) medial carpal-pteroid complex in the wrist;

(3) highly enlarged wing-metacarpal that forms part of the wing spar;

(4) hyperelongated fourth manual digit:

(5) forelimb at least $2 \times$ length of hind limb;

(6) metatarsals i-iv highly elongate, slender and of subequal length:

(7) pedal digit five composed of two elongate phalanges;

(8) penultimate phalanges of both manus and pes elongate.

Dendrorhynchoides appears to lie outside the Pterodactyloidea because it exhibits the primitive condition for all three unambiguous apomorphies of the Pterodactyloidea that can be scored for this pterosaur.

(1) Elongation of the wing (fourth) metacarpal. All pterodactyloids exhibit the derived state for this character wherein the wing-metacarpal always attains at least $0.9 \times$ the length of the humerus. Dendrorhynchoides and other non-pterodactyloids exhibit the primitive state wherein the wing-metacarpal reaches less than $0.9 \times$ the length of the humerus (in Dendrorhynchoides the wing-metacarpal is only $0.33 \times$ the length of the humerus).

(2) Reduction of the fifth pedal digit. Pterodactyloids are characterised by the derived condition in which phalange two is lost and phalange one is reduced to a small nubbin of bone or is absent. Non-pterodactyloids. including Dendrorhynchoides exhibit the primitive condition, in which the fifth pedal digit retains two elongate phalanges (Wellnhofer 1978).

(3) Elongation of the pteroid. Pterodactyloids are characterised by an elongate, slender pteroid. Dendrorhynchoides, and other non-pterodactyloids, exhibit the primitive condition in which the pteroid is a short, stubby structure.

Ji \& Ji (1998) cited the presence of a long tail in support of their assignment of Dendrorhynchoides to the "Rhamphorhynchoidea", but, as discussed above, this character is no longer valid for this taxon. The presence of a short tail in Dendrorhynchoides could be used to argue in support of a relationship with the Pterodactyloidea, because one of the characters that diagnoses the Pterodactyloidea is strong reduction of the tail to a relatively short, pygostyle-like structure (e.g. Bennett 1994). However, a short tail also occurs in the Anurognathidae (Döderlein 1923, Riabinin 1948, Wellnhofer 1975a, Bakhurina 1988), thus it does not provide unequivocal support for the assignment of Dendrorhynchoides to the Pterodactyloidea, a hypothesis of relationships that, in any case, would directly conflict with other character distributions discussed earlier.

The position of Dendrorhynchoides within "Rhamphorhynchoidea" can also be pinned down fairly precisely. Dendrorhynchoides exhibits two clear cut apomorphies of the clade Anurognathidae + Campylognathoididae + Rhamphorhynchidae + Pterodactyloidea (Fig. 4):

(1) Forelimb length more than $2.5 \times$ hind limb length. The basal pterosaurs Preondactylus and the Dimorphodontidae exhibit the primitive condition in which the forelimb is less than $2.5 \times$ the hind limb length.

(2) Ulna longer than the tibia. The basal pterosaurs Preondactylus and the Dimorphodontidae exhibit the primitive condition in which the ulna is shorter than the tibia (Tab. 2).

By contrast, Dendrorhynchoides exhibits the primitive condition for a character that supports the clade Campylognathoididae + Rhamphorhynchidae + Pterodactyloidea (Fig. 4):

(1) Skull elongate with a long, low, preorbital region: Dendrorhynchoides exhibits the primitive condition with a skull that appears to

Fig. 2. Dendrorhynchoides curvidentatus (Ji \& Ji. 1998), holotype (GMV 2128) in dorsal view. Elements located within the shaded rectangle do not appear to form part of the holotype skeleton (see text for details). Abbreviations: ca, carpus; cv, cervical vertebrae: cav. caudal vertebrae: co. coracoid: dv. dorsal vertebrae; f. femur; fi. fibula; h, humerus; i, ii, iii, iv, digits one to four; il, ilium; me. metacarpal; mt. metatarsal: mx. maxilla: n, nasal: pal, palatine; pm, premaxilla; pt, pteroid; pu, pubis; ra, radius; ri, rib; sc. scapula: ti. tibia: ul, ulna: v. pedal digit five. Scale bar $=10 \mathrm{~mm}$ 


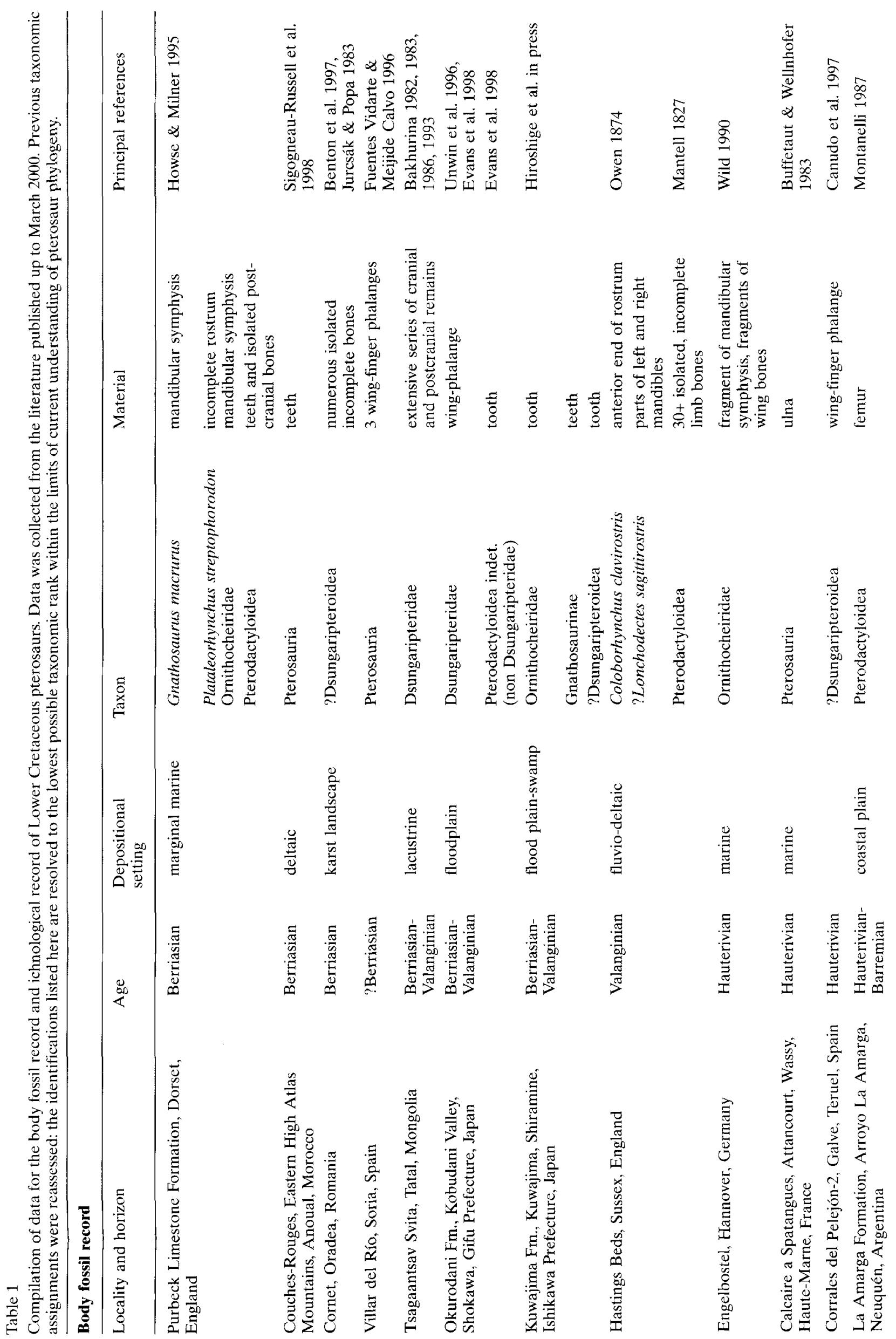




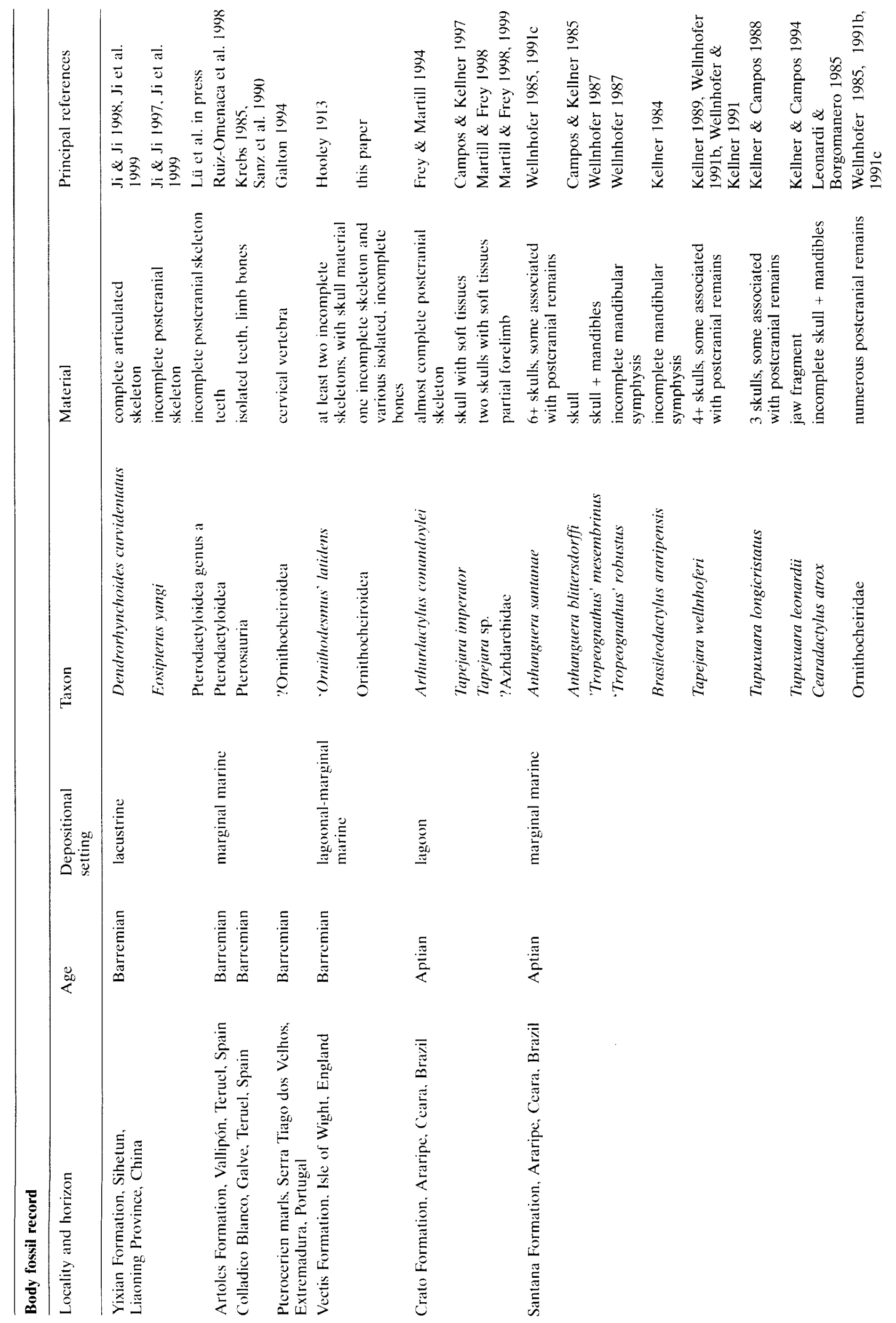




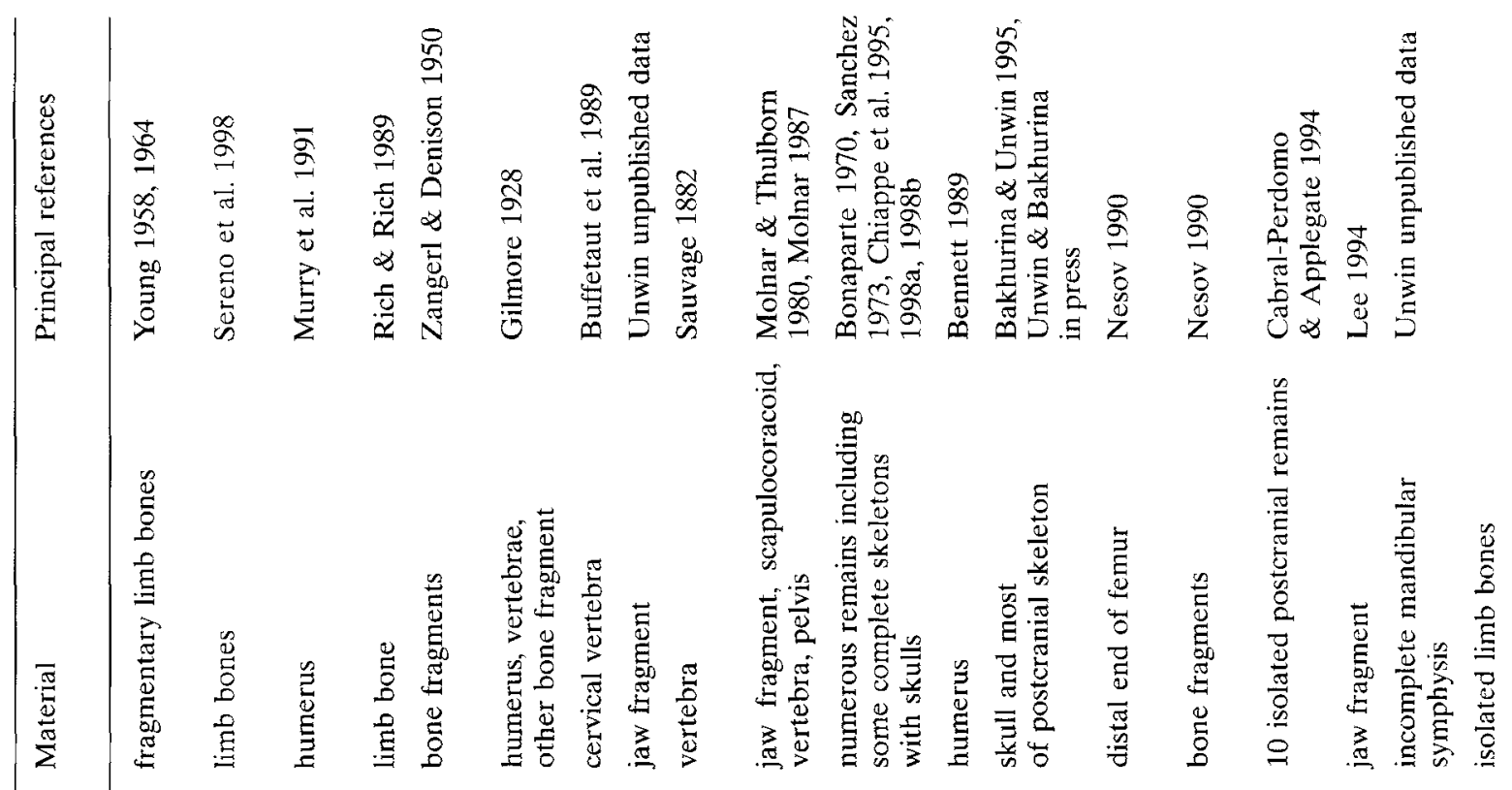

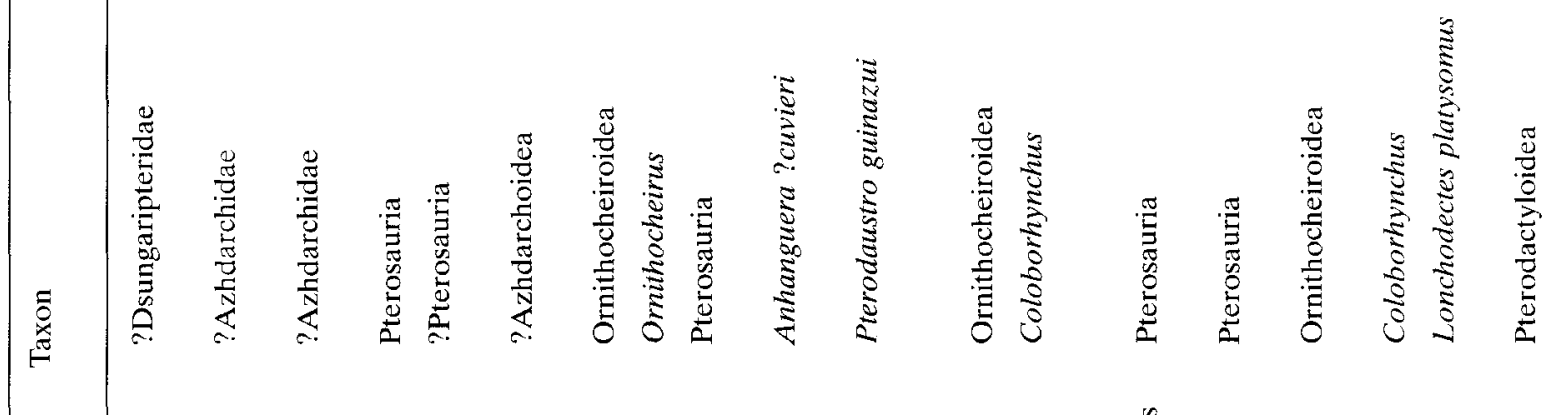

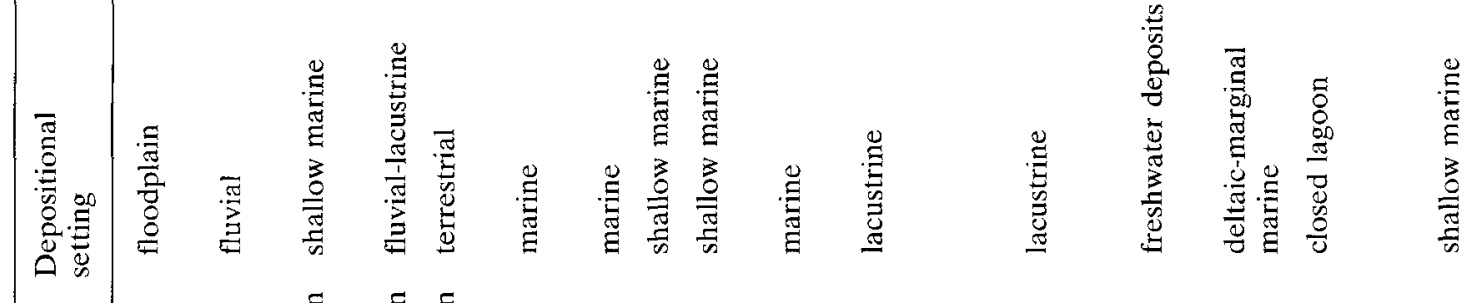

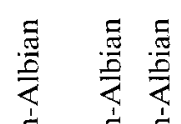

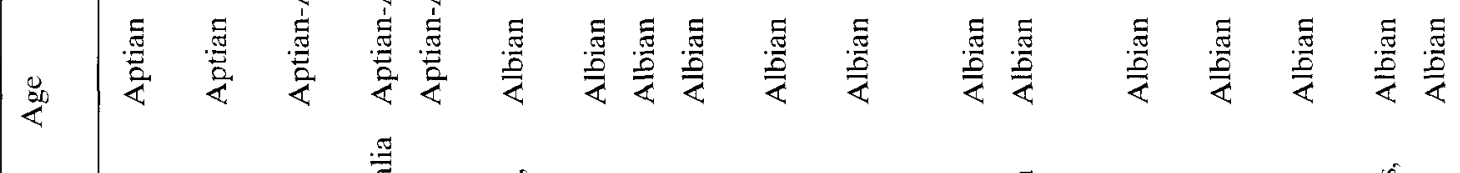

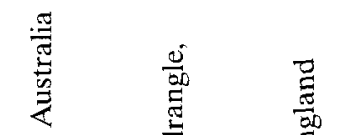

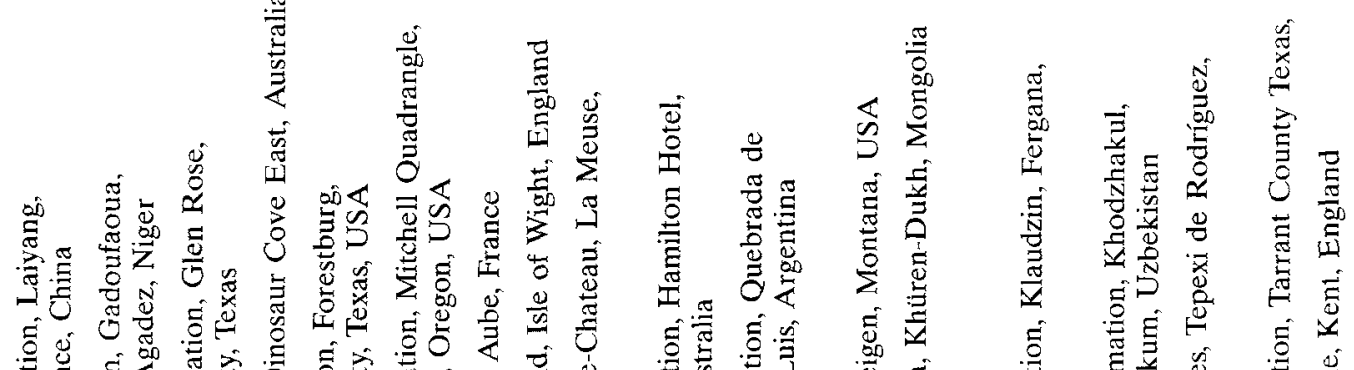

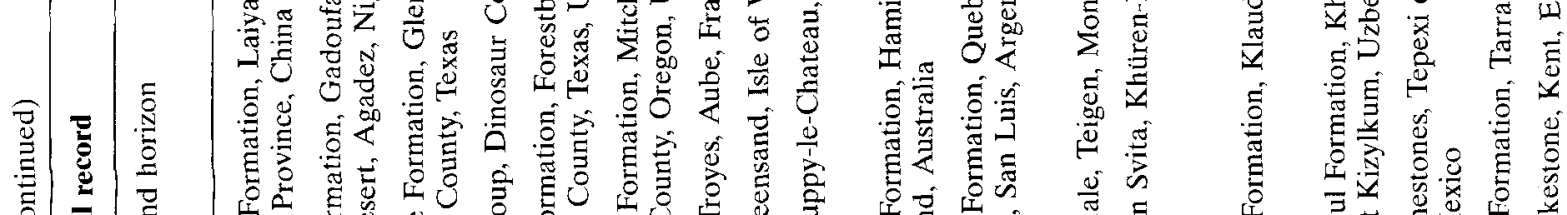

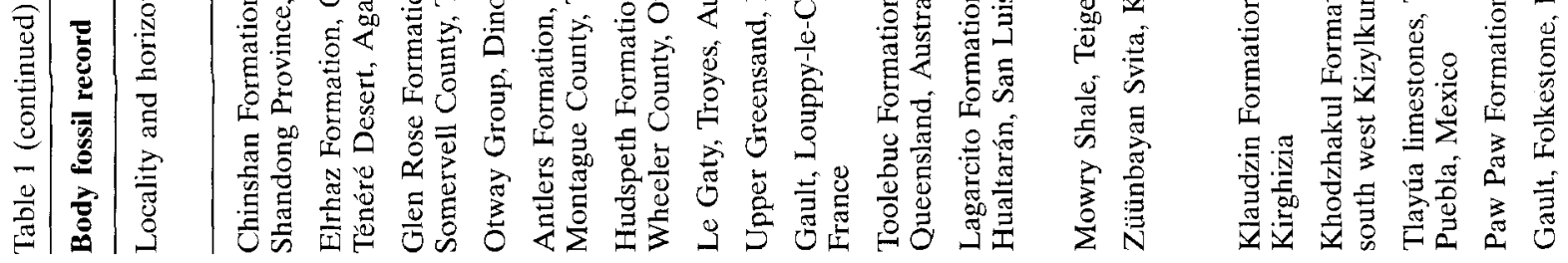




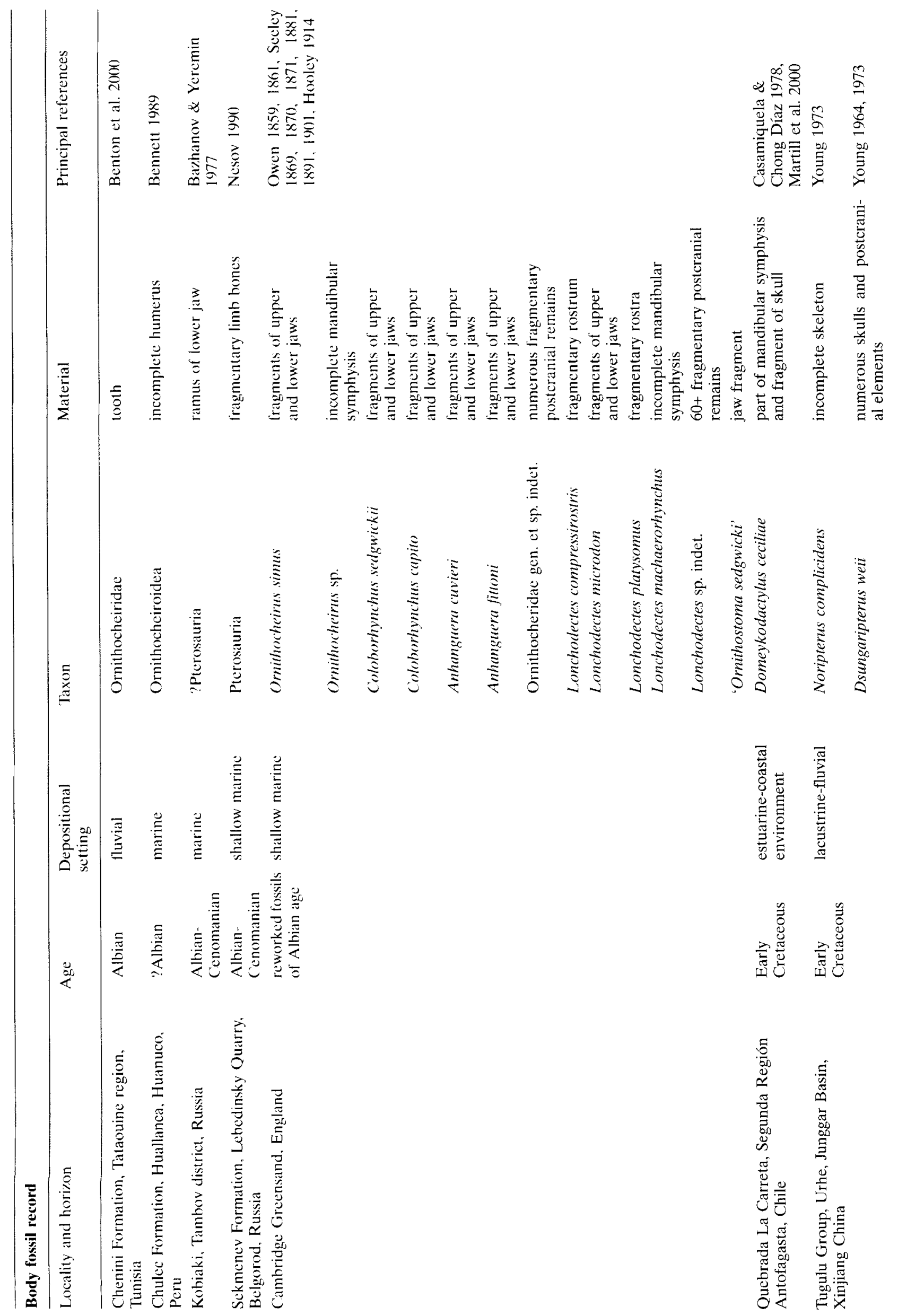




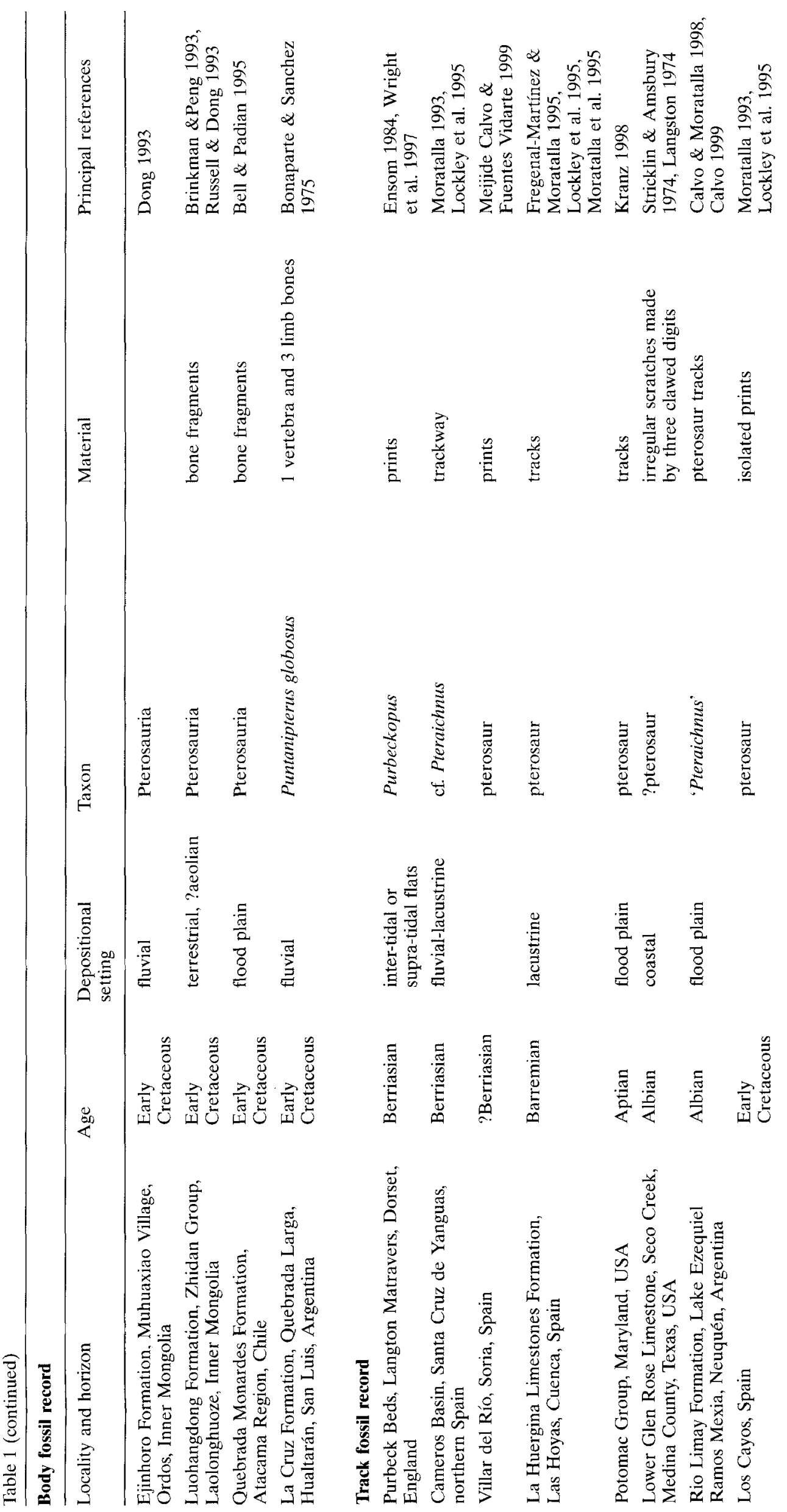


Table 2

Metric data for the DSV and principal elements of the fore and hind limbs of non-pterodactyloid pterosaurs. * = estimate, + = minimum length. Abbreviations: DSV, dorsal+sacral vertebrae: fem. femur: hum, humerus; mc, metacarpal; mt, metatarsal; tib, tibia: ul, ulna; wph, wing-phalange.

\begin{tabular}{|c|c|c|c|c|c|c|c|c|c|c|c|c|}
\hline Taxon & Specimen & DSV & hum & ul & mc4 & wph1 & wph2 & wph3 & wph4 & fem & tib & mt3 \\
\hline Preondactylus buffarinii & MFSN 1770 & 56 & 32 & 42 & 14.3 & 35.5 & 39 & 39 & 28 & 32.5 & 44 & 16 \\
\hline \multicolumn{13}{|l|}{ Dimorphodontidae } \\
\hline Peteinosaurus zambellii & MCSNB 3359 & 82 & 38.5 & 48 & 17 & 43 & 43 & 46.5 & 34.8 & 37 & 49 & 17.5 \\
\hline Dimorphodon macronyx & GSM 1546 & $133.8 *$ & 79 & 102 & $34 *$ & 84 & 93 & 104.6 & 84 & 76 & 105 & \\
\hline \multicolumn{13}{|l|}{ Anurognathidae } \\
\hline Anurognathus ammoni & BSP 1922142 & 46 & 32 & 45 & 11 & 58 & & & & 27 & 39 & 18 \\
\hline Batrachognathus volans & PIN 13 & & 46 & $49.5+$ & & & & & & 30.8 & 41 & 21.8 \\
\hline Dendrorhynchoides curvidentatus & GMV 2128 & $38 *$ & 27.8 & 35.5 & 9.3 & 44.5 & 35.6 & & & $19^{*}$ & 26.7 & 12.1 \\
\hline \multicolumn{13}{|l|}{ Campylognathoididae } \\
\hline Eudimorphodon ranzii & MCSNB 2888 & 103 & 47 & 65 & 29 & $80+$ & & & & 41 & $50+$ & \\
\hline Eudimorphodon rosenfeldi & MFSN 1797 & & 40.5 & 55 & 21 & 64 & 58.2 & 63.2 & 51.5 & 37 & 54.2 & 21 \\
\hline Campylognathoides liasicus & CM 11424 & & 50.3 & 60.3 & 23 & 93.3 & 96 & 84.5 & 69.6 & 37.6 & 47.4 & 21.6 \\
\hline \multicolumn{13}{|l|}{ Rhamphorhynchidae } \\
\hline Sordes pilosus & PIN 2585/3 & 75.6 & 43.1 & 69.1 & 16.5 & 50.5 & 53 & 53.8 & 33.9 & 36 & 49.6 & 14.8 \\
\hline Scaphognathus crassirostris & GPIB 1304 & 110 & 53.5 & 94 & 27 & 70 & 75 & & & 55 & & \\
\hline Dorygnathus banthensis & MB 1905.15 & 121.6 & 62.9 & 106.2 & 31.8 & 79 & 92.3 & 93 & 82.5 & 53.2 & 70 & 29.1 \\
\hline 'Rhamphorhynchus longicaudus' & TM 6924 & 47.5 & 16.5 & 26.7 & 10 & 37 & 31.8 & 28.9 & 32.4 & 12.5 & 15.5 & 9 \\
\hline 'Rhamphorhynchus intermedius' & UB E554 & 57 & 21.8 & 37.5 & 13.7 & 53.8 & 49.4 & 43.5 & 47 & 17 & 22 & 12.8 \\
\hline Rhamphorhynchus muensteri & SMF R 4128 & 107 & 38 & 66 & 21 & 114.5 & 114 & 106.5 & 101 & 33 & 48.5 & \\
\hline 'Rhamphorhynchus gemmingi' & GPIH MYE.13 & 114 & 43 & 68 & 20 & 113 & 108.5 & 98.5 & 102 & 30 & 44 & 28.8 \\
\hline 'Rhamphorhynchus longiceps' & MT & 136 & 64.5 & 96 & 35 & 149 & & & & 45.5 & 64 & 34 \\
\hline
\end{tabular}

have been short and with a relatively short, high preorbital region as in other basal nonpterodactyloids (see below).

In addition, Dendrorhynchoides also exhibits the primitive condition for a character that supports the clade Rhamphorhynchidae + Pterodactyloidea:

(1) Metatarsal iv markedly shorter than metatarsals i-iii. Dendrorhynchoides and other basal non-pterodactyloids (Preondactylus, Dimorphodontidae, Anurognathidae) exhibit the primitive condition wherein metatarsals $\mathrm{i}-\mathrm{iv}$ are of almost the same length.

Ji \& Ji (1998) assigned Dendrorhynchoides to the Rhamphorhynchidae, but it lacks apomorphies that define this taxon (e.g., deltopectoral crest of humerus with constricted base and tongue-like distal expansion; ulna longer than any other fore or hind limb element) or the Rhamphorhynchinae (e.g., tips of mandibles fused into long prow-like symphysis that, together with large fang-like teeth, forms a fish grab; rear edge of wing-phalanges deeply grooved).

Dendrorhynchoides and Rhamphorhynchus share two putative apomorphies (although other members of the Rhamphorhynchidae exhibit the primitive condition for these characters):

(1) Wing-phalange one longer than ulna. Most non-pterodactyloids exhibit the primitive condition where the ulna is longer than the wing-phalange one.

(2) Wing-phalange two longer than ulna. Again, most non-pterodactyloids exhibit the primitive condition where the ulna is longer than wing-phalange two.

However, the derived state of character 1 also occurs in Eudimorphodon, Campylognathoides and Anurognathus (Tab. 2) and the derived state of character 2 also occurs in Campylognathoides (Tab. 2). In view of the homoplasy exhibited by both characters they must be considered as providing only weak support for the pairing of Dendrorhynchoides and Rhamphorhynchus, a relationship that would also require at least seven reversals to the primitive character state in Dendrorhynchoides.

In summary, comparison of Dendrorhynchoides with characters that support principal nodes within the Pterosauria indicates a position at node (a) in the cladogram shown in Figure 4. This suggests a possible relationship with the Anurognathidae and comparison of the two taxa reveals that they share at least four clear cut apomorphies:

(1) Presence of a very short, broad, lightly constructed skull with large cranial openings. All other pterosaurs, even dimorphodontids, have relatively longer, taller and narrower skulls. Anurognathids and Dendrorhynchoides have 
an extremely unusual skull in which the principal bones form a slender frame of thin, fine bars and rods of bone surrounding large cranial vacuities. Many skull bones have a highly distinctive shape quite unlike that seen in other pterosaurs. Thus, the fused premaxillae have the form of an inverted " $T$ " with the left and right maxillary processes diverging at an angle somewhat greater than 90 , rather than less than 45 , as in other pterosaurs. In addition, the maxilla is " $\mathrm{L}$ " shaped with a very short premaxillary process, and the palatine is reduced to a very slender " $Y$ " shaped bone, the stem of which contacted the maxilla on its medial surface. These features are present in Anurognathus (Wellnhofer 1975a: fig. 38) and Batrachognathus (Riabinin 1948: fig. 1) and are also clearly evident in Dendrorhynchoides (Fig. 2). Indeed, the anurognathid skull presents a large complex of derived characters that are diagnostic of this clade, though they have yet to be documented in detail.

(2) The combined length of the dorsal + sacral vertebrae (= DSV) is of almost the same length as the ulna (Tab. 2). In pterosaurs other than anurognathids and Dendrorhynchoides the DSV is always substantially longer than the ulna (Fig. 5), which, as outgroup comparison with other diapsids shows, is the primitive condition. Anurognathids are unusual in that the DSV is remarkably short, principally because of the relatively low number of dorsal vertebrae (12, compared to 14-16 in Rhamphorhynchus) and their relative shortness.

(3) Sub-symmetric, angular profile of the proximal end of the humerus in dorsal view. In anurognathids and Dendrorhynchoides the deltopectoral and medial crests on the proximal end of the humerus are of similar size and shape, with a broad base and straight, angular outline. These, and the practically flat proximal surface of the caput humeri give the humerus a highly distinctive profile that is unlike that found in other pterosaurs, where, for example, the deltopectoral crest is always considerably larger than the medial crest (Wellnhofer 1978: fig. 10). The humerus of Dendrorhynchoides (Fig. 3) is similar to that of Anurognathus (Wellnhofer 1975a: fig. 37) and Batrachognathus (Riabinin 1948: fig. 1), but is not quite so symmetrical, and the deltopectoral crest is directed a little more proximally than in other anurognathids.

Table 3

Metric data for the principal elements of the fore and hind limbs of pterodactyloid pterosaurs. $*=$ estimate, $+=$ minimum length. Abbreviations as for Table 2.

\begin{tabular}{|c|c|c|c|c|c|c|c|c|c|c|c|}
\hline Taxon & Specimen & hum & $\mathbf{u l}$ & mc4 & wph1 & wph2 & wph3 & wph4 & fem & tib & mt3 \\
\hline \multicolumn{12}{|l|}{ Ornithocheiroids } \\
\hline Arthurdactylus conandoylei & SMK 1132 PAL & 230 & 312 & 227 & 445 & 402 & 312 & 275 & 190 & 234 & 60 \\
\hline Anhanguera santanae & NSM PV 19892 & 257 & 384 & 257 & $462^{*}$ & $387 *$ & $270^{*}$ & $225^{*}$ & 236 & $283^{*}$ & 59 \\
\hline Pteranodon & Bennett 1991 & 250 & 344 & 548 & 615 & 499 & 346 & 194 & 250 & 328 & \\
\hline Nyctosaurus gracilis & UNSM 2/85 & 94 & 142 & $255^{*}$ & 308 & 245 & 122 & & 85 & 120 & 38 \\
\hline \multicolumn{12}{|l|}{ Ctenochasmatoids } \\
\hline Cycnorhamphus suevicus & $\mathrm{MT}$ & 65.5 & 87 & 108 & 141 & 115.2 & 85 & 77.5 & 77 & 122 & 30 \\
\hline Cycnorhamphus canjuersensis & MNHN & & & $85+$ & 155 & 134 & 94 & $67+$ & 101 & 138 & 35 \\
\hline Pterodactylus antiquus & BSP AS I 739 & 31.5 & 47 & 35 & 48.5 & 44.2 & 37 & 28.5 & 34.7 & 48.3 & 19 \\
\hline Pterodactylus kochi & BSP 1937 I 18 & 29 & 39 & 27.5 & 38.5 & 36.5 & 32.5 & 27 & 28.5 & 38.5 & 14.5 \\
\hline Pterodactylus micronyx & BSP 1911 I 31 & 25 & 31 & 40 & 46 & 28.5 & 19.5 & 17.7 & 29 & 40.5 & 8.7 \\
\hline Pterodactylus longicollum & SMNS & 78 & 104 & 130 & 160 & 109 & 77.5 & 65 & 99 & 149 & 30 \\
\hline 'Pterodactylus' elegans & BSP 1867 II 1 & 15 & 18.2 & 16.5 & 19.5 & 17.8 & 14.3 & 12.8 & 12.3 & 17.6 & 5.6 \\
\hline Ctenochasma gracile & BSP 1935 I 24 & 38.5 & 52.5 & 35 & 66 & 57 & & & 35 & 55 & 21 \\
\hline Pterodaustro guinazui & PVL 3860 & 80 & 102 & 78 & 116 & 112 & 86 & 69 & 60 & 90 & 50 \\
\hline Eosipterus yangi & GMV 2117 & $34+$ & 95 & 73 & 96 & 95 & 80 & 73 & 60 & 96 & 38.5 \\
\hline \multicolumn{12}{|l|}{ Dsungaripteroids } \\
\hline Germanodactylus rhamphastinus & BSP 1977 XIX 1 & 51 & 76 & 58 & 75 & 69.5 & 58.5 & 40.4 & 53 & 80.4 & 25.8 \\
\hline Germanodactylus cristatus & BSP 1892 IV 1 & 56 & 75 & 66 & 84 & 77.5 & 65.5 & 55 & 56.5 & 87.5 & 24 \\
\hline Noripterus complicidens & IVPPP $64043-3$ & 76 & 104 & 142 & 174 & 124 & $44.5+$ & & 87 & 160 & 32 \\
\hline \multicolumn{12}{|l|}{ Azhdarchoids } \\
\hline Tupuxuara longicristatus & IMCF 1052 & 234 & 291 & 359 & 505 & 301 & 208 & & 298 & 398 & 88.2 \\
\hline Zheijiangopterus linhaiensis & ZMNH M1323 & 137 & 234 & 336 & 322 & 220 & & & 222 & 265 & \\
\hline Quetzalcoatlus sp. & TMM 42422 & 250 & 358 & 620 & 602 & 305 & 156 & 39 & & 604 & \\
\hline
\end{tabular}


(4) The combined length of the caudal vertebrae is shorter than either the cervical or dorsal series. By contrast to all other non-pterodactyloids, which have a caudal series that is longer than either the cervical or dorsal series (and often longer than the two combined), in anurognathids, the tail is reduced to a remarkably short, pygostyle-like structure (e.g. Riabinin 1948, Döderlein 1923: fig. 4). This is similar to the condition in pterodactyloids, but is presumably the result of homoplasy since the Rhamphorhynchidae, members of which have long tails, appear to be more closely related to the Pterodactyloidea than the Anurognathidae (Unwin 1995; Fig. 4). Dendrorhynchoides appears to have a tail that is of the same shape and proportions as those of anurognathids.
In addition to the apomorphies discussed above, the skeletal morphology of Dendrorhynchoides is remarkably similar to that of Anurognathus and Batrachognathus in many other respects, including its relative dimensions (Tab. 2). The following characters are putative synapomorphies uniting Dendrorhynchoides and anurognathids:

(1) Short, conical, sharp-pointed, widely spaced teeth with slightly recurved tips showing little size variation along the jaw. Teeth with a similar morphology occur in some species of Pterodactylus, but are usually more closely spaced and do not have recurved tips.

(2) Wing-phalange one longer than the combined length of the ulna + wing-metacarpal. In all other non-pterodactyloids, with the exception of Rhamphorhynchus and Campylog-

Table 4

Classification, to the generic level. of all pterosaur taxa referred to in the text. Tables 1-3 and in Figures 1 and 4-7. The interrogative mark indicates that there is some ambiguity regarding the position of a particular taxon within the next higher rank taxon

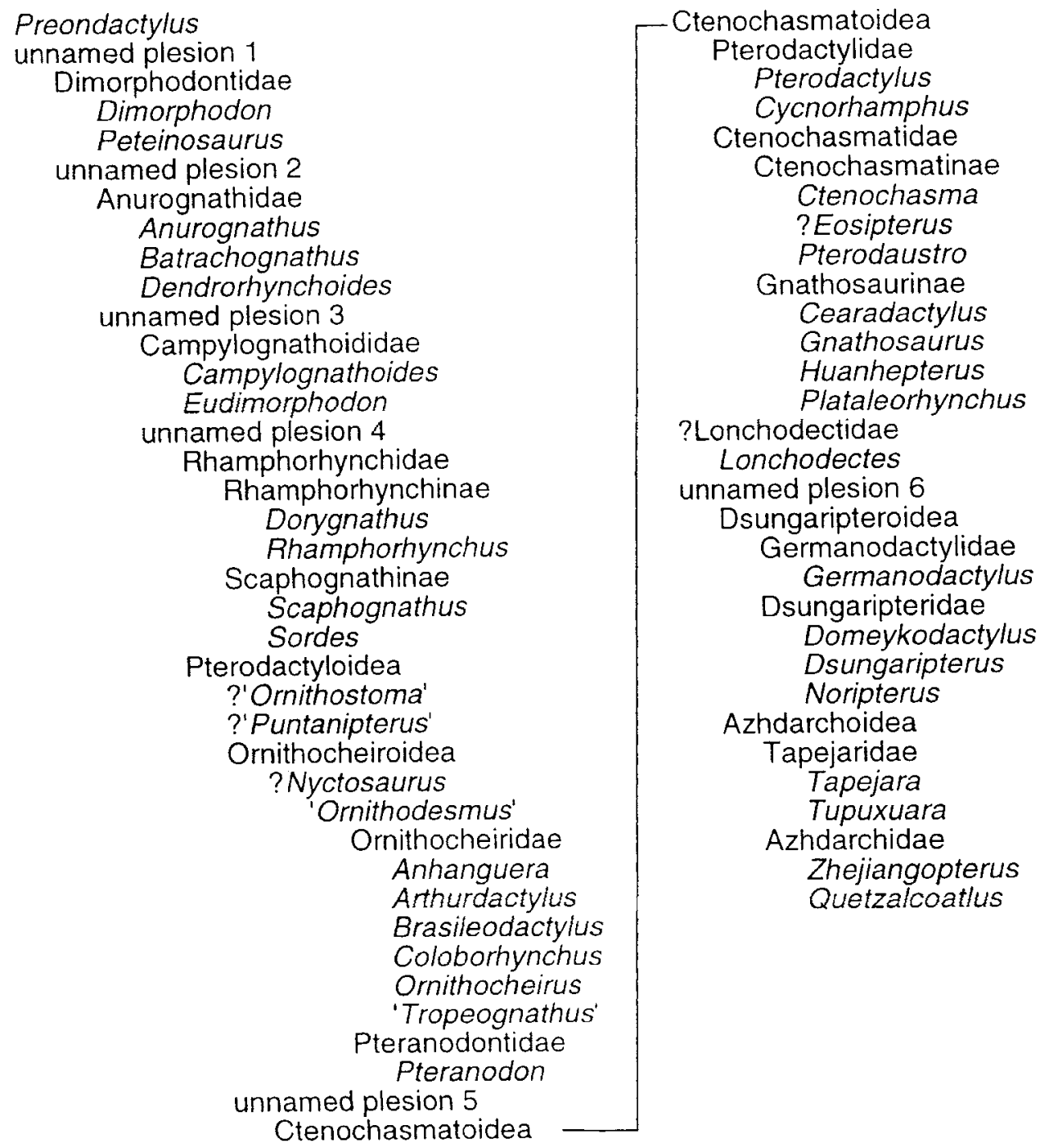


nathoides, wing-phalange one is shorter than the ulna + wing-metacarpal (Tab. 2). Basal members of the Rhamphorhynchidae and Campylognathoididae exhibit the primitive condition for this character suggesting that the derived condition was independently attained in anurognathids and the other two families.

(3) Wing-phalange two longer than the ulna. This character is only known for Dendrorhynchoides among anurognathids, because a complete wing-phalange two is not preserved in specimens of Batrachognathus and Anurognathus - thus while it is a putative anurognathid apomorphy, more complete material of other taxa is needed to confirm this. In all other pterosaurs, with the exception of Rhamphorhynchus, the ulna is longer than wing-phalange two (Tab.2). More basal members of the Rhamphorhynchidae exhibit the primitive condition, thus the derived state is presumably homoplastic for Rhamphorhynchus and anurognathids.

In summary, Dendrorhynchoides and anurognathids are united by four unique characters (one of which is a character complex consisting of at least three characters) and this relationship is supported by a further three putative apomorphies. In addition, these taxa also appear to have a very similar general morphology and proportions (Tab. 2). By contrast, Dendrorhynchoides does not share any derived characters in common with other non-pterodactyloid taxa, the sole exception being Rhamphorhynchus, and in this case character optimisation is ambiguous. In the face of such overwhelming evidence we have no doubt in assigning Dendrorhynchoides to the Anurognathidae (Tab. 4).

\section{Pterodactyloidea Plieninger, 1901 \\ Ctenochasmatoidea Kuhn, 1967 \\ ?Ctenochasmatidae Nopcsa, 1928 \\ Eosipterus Ji \& Ji, 1997 \\ Eosipterus yangi Ji \& Ji, 1997}

Fig. 3

The holotype and only known specimen of Eosipterus (GMV 2117) was collected from lacustrine sediments in the upper part of the Hengdaozi Member of the Yixian Formation at the locality of Tuanshangou (Wang et al. 1999), in the Sihetun region, south of Beipiao City, in western Liaoning Province, China (Ji \& Ji 1997). The specimen consists of an incomplete skeleton in- cluding almost complete right fore and hind limbs, partial left fore and hind limbs, gastralia, and parts of the pelvis (Fig. 3). The skeleton is, for the most part, naturally articulated, although the left wing appears to have undergone some disruption. The current disposition of the fore and hind limbs is similar to that observed, for example, in pterodactyloids from the Solnhofen Limestone (Wellnhofer 1970). A brief description together with measurements of the principal limb bones and illustrations was given by $\mathrm{Ji} \& \mathrm{Ji}$ (1997), and a sketch of the skeleton is reproduced here (Fig. 3). GMV 2117 represents a relatively small pterodactyloid with a wingspan of about $1.25 \mathrm{~m}$, although, as Ji Shu'an et al. (1999) note, the absence of fusion of some elements suggests that it had not reached adulthood.

The single specimen of Eosipterus is far less complete than that of Dendrorhynchoides and lacks a skull, cervical vertebrae, or well preserved humerus, all of which are important for determining the systematic relationships of pterosaurs (Wellnhofer 1970, 1975a, 1978, Howse 1986, Padian 1984, Unwin \& Lü 1997). The main source of evidence regarding the relationships of Eosipterus consists of comparative lengths of the major limb bones. This type of data is often of taxonomic significance, and has frequently been used in systematic studies of pterosaurs (e.g. Wellnhofer 1970, 1975a, Wild 1978, 1984, 1993 , Padian 1980), but is not without problems. Ontogenetic variation, for example, can be quite marked in some pterosaurs (Bennett 1995, 1996). but this variable has yet to be fully incorporated into morphometric analyses.

Previous studies (Ji \& Ji 1997, Ji Shu'an et al. 1999) have consistently identified Eosipterus as a pterodactyloid and this is supported by the presence of two unambiguous apomorphies of the Pterodactyloidea:

(1) The wing-metacarpal is more than $1.5 \times$ the length of the third metatarsal (in Eosipterus this ratio $=1.9$ ). In non-pterodactyloids the wing-metacarpal reaches, at most, $1.3 \times$ the length of the third metatarsal, but is usually shorter than the latter element.

(2) The fifth pedal digit is highly reduced and represented by just a single, short nubbin of bone. In non-pterodactyloids the fifth toe is composed of two elongate phalanges (see above).

Pterodactyloids can be subdivided into four major clades: the Ornithocheiroidea, Ctenochasmatoidea, Dsungaripteroidea and Azhdarchoidea (Unwin 1995, Unwin \& Lü 1997; Fig. 4). In so 


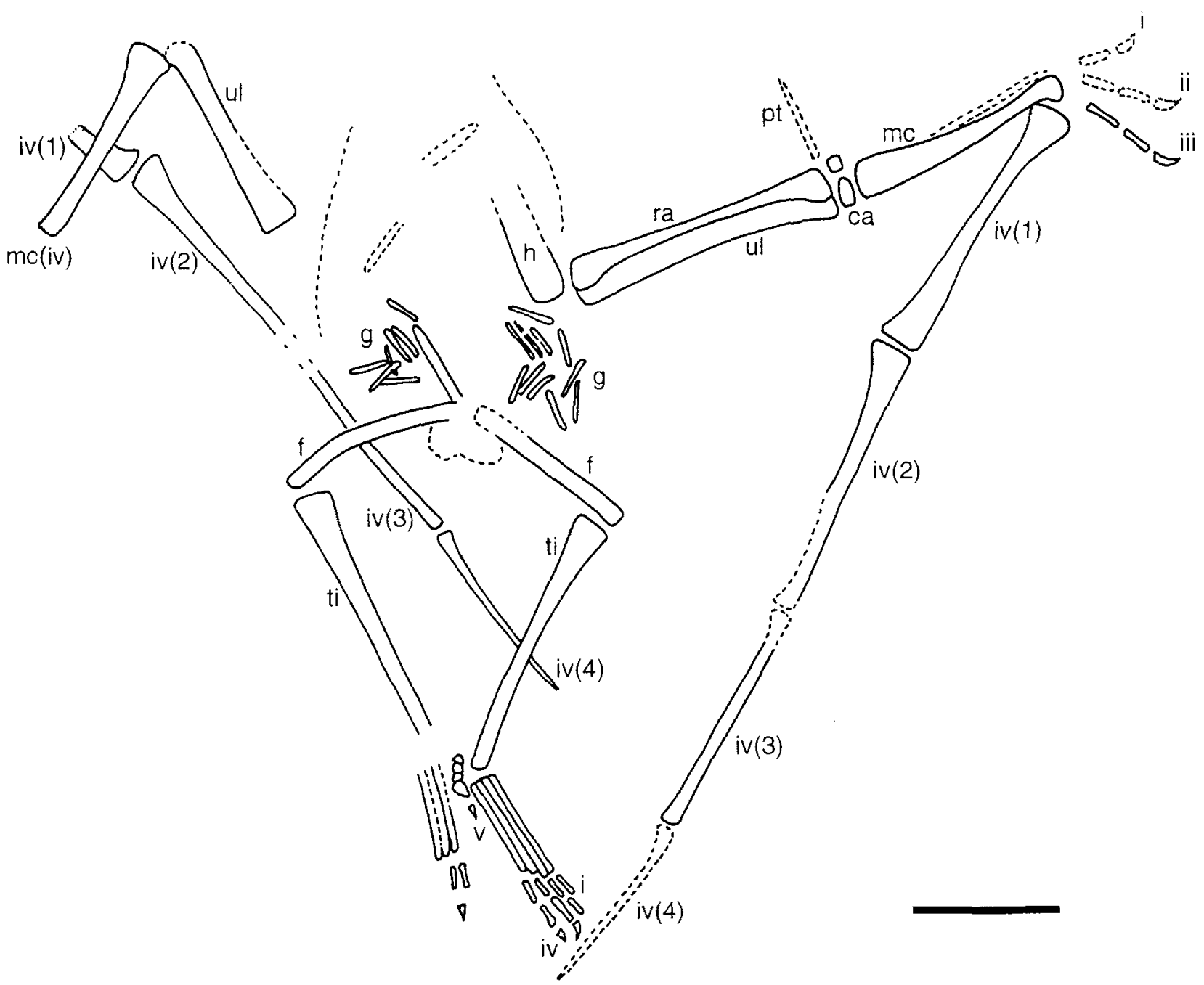

Fig. 3. Eosipterus yangi Ji \& Ji. 1997, holotype (GMV 2117) in dorsal view.

Abbreviations as for Figure 2. except: g. gastralia. Scale bar $=50 \mathrm{~mm}$

far as comparisons can be made, Eosipterus exhibits the primitive condition for postcranial apomorphies of ornithocheiroids. dsungaripteroids and azhdarchoids (see Unwin 1995. Unwin \& Lü

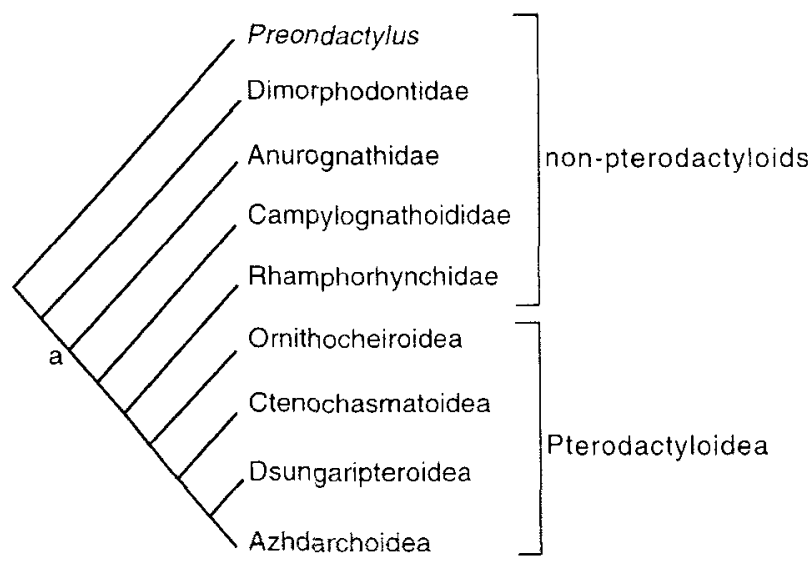

Fig. 4. Hypothesis of phylogenetic relationships of the main clades of pterosaur. After Unwin (1995) and Unwin \& Lü (1997)
1997). It does, however, have a relatively long third metatarsal, a character that is typical of some ctenochasmatoids (Fig. 6a). Moreover, in its general proportions Eosipterus also compares well with ctenochasmatoids, as shown by the results of the morphometric analysis carried out by Ji Shu'an et al. (1999), which grouped Eosipterus with Pterodactylus - a basal member of the Ctenochasmatoidea.

The Ctenochasmatoidea comprise a series of Late Jurassic and Early Cretaceous taxa. Basal members of the clade include Pterodactylus and Cycnorhamphus, traditionally placed in the Pterodactylidae (e.g. Wellnhofer 1978), although this taxon is probably paraphyletic as some species appear to be more closely related to the Ctenochasmatidae than to other members of the Pterodactylidae. The Ctenochasmatidae, characterised by remarkably elongate jaws and large numbers of teeth that form a filtering apparatus (e.g. Wellnhofer 1970), consists of two clades: the 


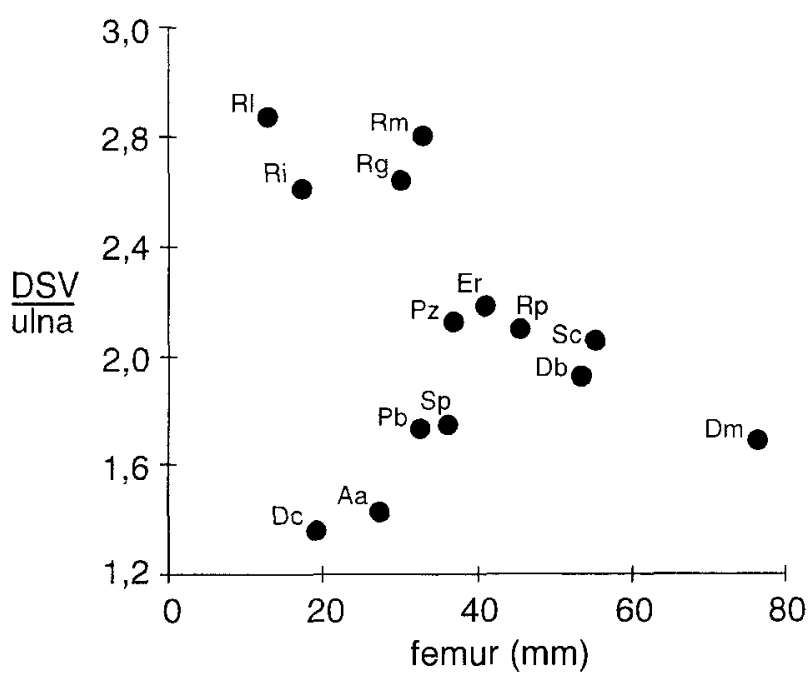

Fig. 5. Comparison of the relative lengths of the DSV (dorsal + sacral vertebrae) to the ulna, plotted against femur length, for non-pterodactyloid pterosaurs. Comparing the DSV with other limb bones results in the same basic distribution of points. Bennett (1995) and Unwin (1995) have argued that the five species of Rhamphorhynchus indicated here represent a single species. Four species do indeed cluster separately and show little variation, other than in size, but, by contrast, Rhamphorhynchus longiceps has a relatively long ulna and plots within the main cluster of points. Abbreviations: Aa, Anurognathus ammoni; Db, Dorygnathus banthensis; Dc, Dendrorhynchoides curvidentatus; Dm, Dimorphodon macronyx; Er, Eudimorphodon ranzii; $\mathbf{P b}$, Preondactylus buffarinii; $\mathbf{P z}$, Peteinosaurus zambellii; Rg, 'Rhamphorhynchus gemmingi'; Ri 'Rhamphorhynchus intermedius'; RI, 'Rhamphorhynchus longicaudus'; Rm, Rhamphorhynchus muensteri; Rp, 'Rhamphorhynchus longiceps'; Sc, Scaphognathus crassirostris; $\mathbf{S p}$, Sordes pilosus

a

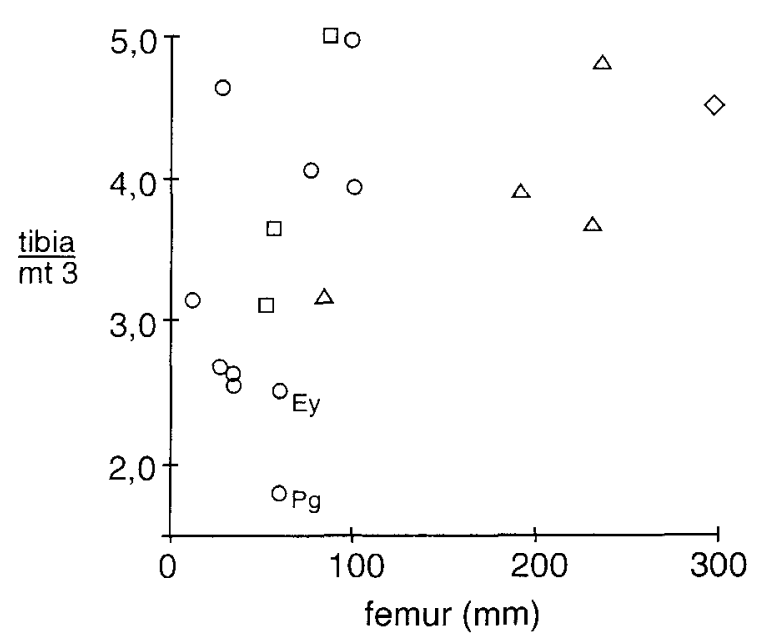

gnathosaurines comprising Gnathosaurus, Plataleorhynchus, Huanhepterus and Cearadactylus; and the ctenochasmatines, comprising Ctenochas$m a$ and Pterodaustro.

In the absence of skull material it is difficult to resolve the relationships of Eosipterus to other ctenochasmatoids. We note, however, that Eosipterus is of very similar size and proportions to Pterodaustro (Tab. 3). Moreover, in some respects, such as the relative length of the femur to the ulna (Fig. 6b) or to the wing-phalange two, and the length of the third metatarsal compared to the wing-phalange one, or the tibia (Fig. 6a), Eosipterus exhibits proportions that, among ctenochasmatoids, are most similar to those of Pterodaustro and Ctenochasma.

In summary, there is some evidence to suggest that Eosipterus is a ctenochasmatoid and probably belongs within the Ctenochasmatidae rather than sharing a close relationship with Pterodactylus. However, confirmation of this assignment must await the discovery of more complete material of Eosipterus.

\section{Discussion}

\section{Palaeoecology of Lower Cretaceous pterosaurs}

The vast majority of pterosaur remains have been recovered from marginal marine or marine

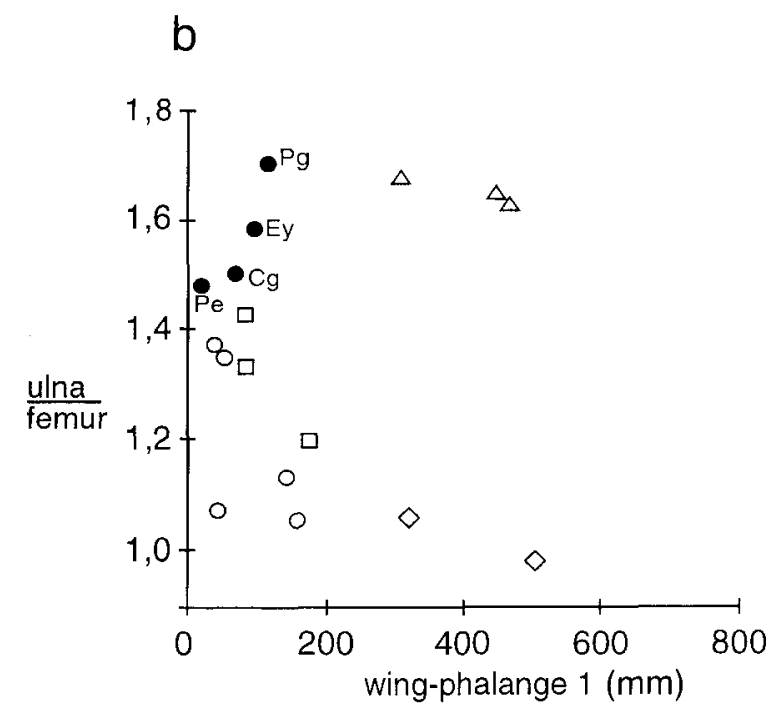

Fig. 6. Comparison of the third metatarsal to the tibia, plotted against femur length (a) and of the femur to the ulna, plotted against length of wing-phalange one (b) for 18 species of pterodactyloid pterosaurs. Symbols: triangle = ornithocheiroids, circle $=$ ctenochasmatoids, square $=$ dsungaripteroids, diamond $=$ azhdarchoids. In (b) ctenochasmatines are indicated by filled circles. Note that the location of 'Pterodactylus elegans' is consistent with Bennett's contention (1996) that individuals assigned to this species are juveniles of Ctenochasma elegans. Abbreviations: Ey, Eosipterus yangi, Cg, Ctenochasma gracile, Pe. 'Pterodactylus elegans', Pg, Pterodaustro guinazui. The dispersion of points in plot (b) provides some further support for the systematic arrangement utilised in this paper: for example, azhdarchoids have a very low ulna/femur ratio, while ornithocheiroids and ctenochasmatines have relatively high ratios 
deposits and, as is well known. records from continental sediments are rare and generally fragmentary (Wellnhofer 1991a, Bell \& Padian 1995. Bakhurina \& Unwin 1996). The fossil assemblage from the Yixian Formation thus provides a useful source for new insights into the palaeoecology of pterosaurs in terrestrial ecosystems.

With regard to the specific palaeoecologies of the Yixian pterosaurs, it seems likely that Dendrorhynchoides, which has a skull morphology remarkably similar to that of other anurognathids, was a small. aerial insectivore. This inference is based on the occurrence. in anurognathids, of relatively small, widely spaced peglike teeth, which seem well suited for gripping and puncturing the chitinous exoskeletons of insects (Döderlein 1923. Wellnhofer 1975b). In addition, the jaws of anurognathids had a relatively large gape, that was further extended by a fringe of "hair-like" structures (Bakhurina \& Unwin 1995), in a fashion analogous to that of some caprimulgiforms such as Podargus and Caprimulgus, which also hawk for insects (Tyne \& Berger 1976). That potential prey items were abundantly available is demonstrated by the large and diverse insect fauna that has also been recovered from the Yixian deposits (Lin 1998). It may also be significant that the other three deposits that have yielded anurognathids (Bakhar Formation, Bakhar. central Mongolia: Karabastau Formation, Karatau. Kazakhstan and the Solnhofen Limestones. southern Germany) have also yielded large insect faunas.

The palaeoecology of Eosipterus is far less certain. Assuming that it was a ctenochasmatine it seems likely that this pterosaur had elongate jaws with numerous. long fine teeth that functioned as a sieve or filtering device. It has recently been shown that pterodactyloid pterosaurs had a reasonably effective quadrupedal stance and gait (Bennett 1997. Unwin 1997. 1999. Henderson \& Unwin 1999, Unwin \& Henderson 1999). thus Eosipterus may be envisioned proceeding on stiltlike fore and hind limbs through streams and along the shallow margins of lakes and rivers sieving for small, soft-bodied crustaceans, the aquatic larvae of insects. other invertebrates and perhaps even fish fry. Again, suitable prey items are known from sediments of the Jehol Group: Chen (1988) has described a diverse freshwater invertebrate fauna, and fish that lived and presumably reproduced in the ancient Liaoning lakes have also been reported (Jin et al. 1995. Jin 1996).

We emphasise. therefore. that the putative palaeoecologies proposed for the Yixian pterosaurs are consistent with what is known of the co-occurring invertebrate and vertebrate fauna. This supports the idea that these pterosaurs inhabited the Sihetun lakes region and formed an integral part of this Lower Cretaceous terrestrial ecosystem, rather than representing accidental occurrences of individuals displaced from elsewhere by unusual conditions, for example, storms, volcanic activity or disrupted migration patterns.

A new compilation of the Lower Cretaceous pterosaur fossil record, including the taxa from Liaoning (Tab. 1) indicates that, for this interval, pterosaurs are now known from more than 20 localities that represent fully terrestrial settings. Moreover, these localities are widely distributed across three continents, and represent a range of palaeoenvironments from shallow, freshbrackish water, inland lakes with low diversity faunas and floras (e.g. Tsagaantsav Svita, Tatal, western Mongolia: Bakhurina 1983, 1984, 1986), to well vegetated lowland areas with large and diverse invertebrate and vertebrate communities (e.g. Yixian beds, Liaoning: Barrett 2000 and refs therein). This reinforces the idea that pterosaurs were a typical, if not particularly diverse, component of Lower Cretaceous terrestrial ecosystems. Consequently, their absence from many Lower Cretaceous vertebrate localities can probably be attributed to taphonomic bias rather than true absence. This interpretation is supported by the discovery of pterosaur tracks at localities such as Las Hoyas (Fregenal-Martínez \& Moratalla 1995, Lockley et al. 1995) that have yielded a diverse terrestrial fauna, but, as yet, no skeletal remains of pterosaurs (Meléndez 1995).

Comparison of the Yixian pterosaurs with assemblages from other Lower Cretaceous localities (Tab. 1) provides an important new insight into pterosaur palaeoecology during this interval. Similar sedimentologic/biotic associations to those of the Yixian Formation are rare, but a new fossil biota, from the Kuwajima Formation of Shiramine, Ishikawa Prefecture, Japan (Manabe et al. 2000, Hiroshige et al. 2000), forms one possible example. The Kuwajima Formation consists of fluviatile and swamp sediments of Early Cretaceous (Berriasian) age that have yielded a diverse freshwater assemblage (Evans et al. 1998, Manabe et al. 2000, Hiroshige et al. 2000). Pterosaurs are only known from teeth, most of which represent a medium to large sized ctenochasmatoid. though dsungaripterid and ornithocheirid teeth have also been identified. The Lagarcito Formation of Argentina, currently dated as Low- 


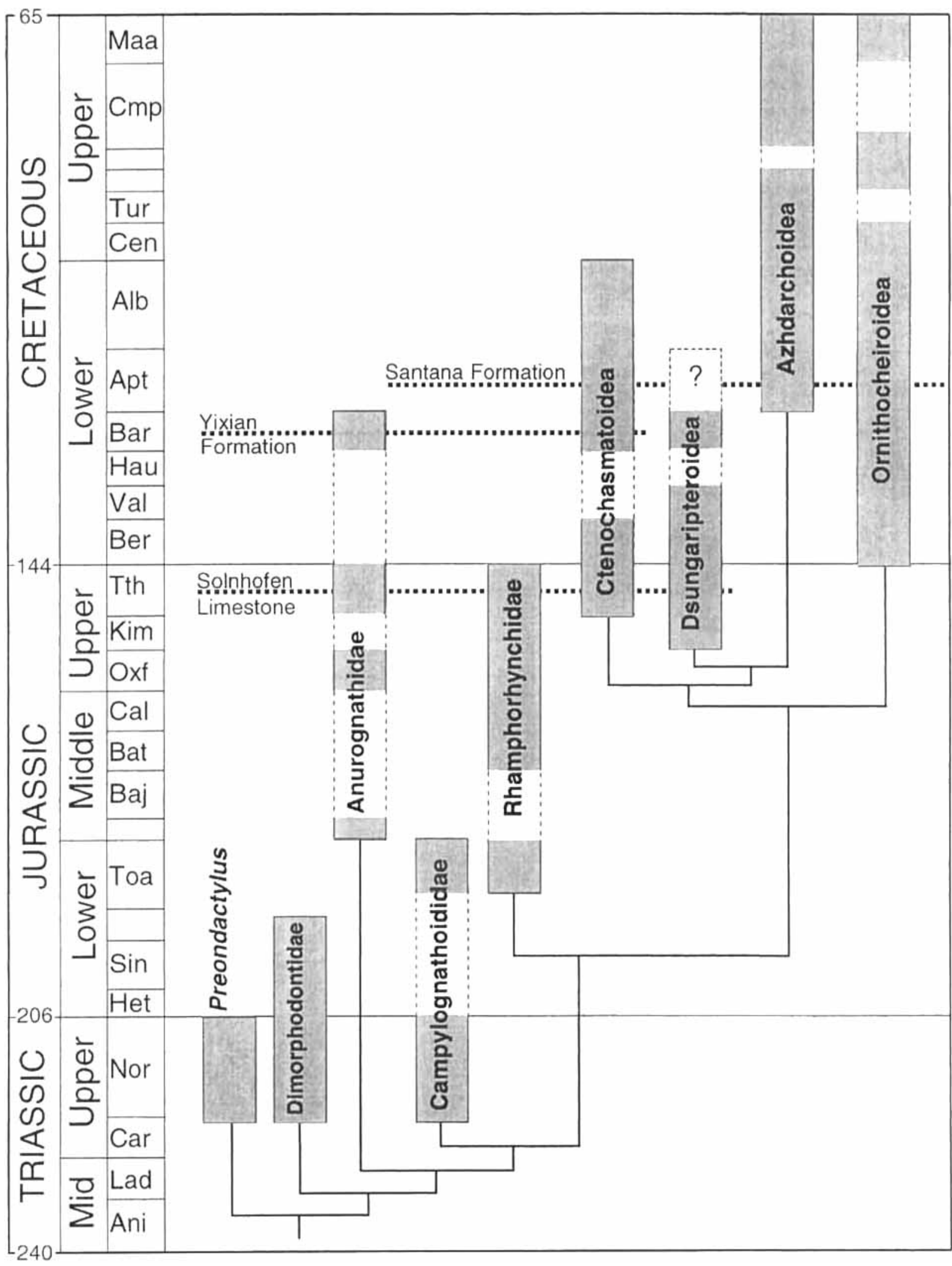

Fig. 7. Stratigraphic range of main pterosaur clades. Tree topology follows that shown in Figure 4. Stage length based on Geological Society of America Timescale 1999. Fossil record data compiled from literature published up to March 2000. Each column represents the known extent of a particular lineage with blank sections indicating gaps in the fossil record. The age of most records can only be resolved, at best, to the stage level, thus the entire stage is shown as represented if any records fall within the stage.

Abbreviations: Alb, Albian; Ani, Anisian; Apt, Aptian; Baj, Bajocian; Bar, Barremian; Bat, Bathonian; Ber, Berriasian; Cal, Callovian; Car, Carnian; Cen, Cenomanian; Cmp, Campanian; Hau, Hauterivian, Het, Hettangian; Kim, Kimmeridgian; Lad, Ladinian; Maa, Maastrichtian; Nor, Norian; Oxf, Oxfordian, Sin, Sinemurian; Toa, Toarcian; Tth, Tithonian; Tur, Turonian; Val, Valanginian 
er Cretaceous (Albian) is also broadly analogous with the Yixian Formation in that it also represents a large. shallow, freshwater lake that has yielded fish. conchostracans. plants and a ctenochasmatine, Pterodaustro (Chiappe et al. 1995. 1998a, b).

In sharp contrast. other continental localities have produced strikingly different pterosaur assemblages. For example. shallow, fresh-brackish water lake sediments in western Mongolia and China, that were deposited in semi-arid. or arid conditions, have produced low diversity biotas dominated by, or in some cases consisting solely of a single species of dsungaripterid pterosaur, often represented by large numbers of remains (Young 1964, 1973, Bakhurina 1982, 1986, 1993. Dong 1992).

Pterosaurs from marginal marine or fully marine settings are different again from those found in continental environments. Pterosaur assemblages from deposits such as the Santana Formation of Brazil (Wellnhofer 1991b). the Toolebuc Formation of Australia (Molnar \& Thulborn 1980, Molnar 1987) and the Paw Paw Formation of Texas (Lee 1994) are dominated by, or consist entirely of ornithocheirids, medium to very large pterosaurs specialised in aerial piscivory (Wellnhofer 1991a).

In summary, this brief analysis of the palaeoenvironmental distribution of Lower Cretaceous pterosaurs suggests that two broad palaeoecological distinctions can be made: first. between pterosaurs inhabiting marine and continental environments, and second, within continental environments, between lowland communities such as the Liaoning assemblage, and more specialised inland ecosystems such as the dsungaripterid dominated assemblages of western China and Mongolia. The apparent palaeoecological and systematic diversity of Lower Cretaceous pterosaur is in distinct contrast to the situation in the latest Cretaceous (Campanian-Maastrichtian) wherein continental and marine assemblages are dominated by just a single family of pterosaurs. the Azhdarchidae.

\section{Evolutionary significance of the Yixian pterosaurs}

The Yixian pterosaurs also contribute significantly to our understanding of the evolutionary history of pterosaurs. As mentioned above. the Lower Cretaceous fossil record is patchy, with a distinct gap between the better represented basal Cretaceous and late Early Cretaceous assem- blages (Fig. 1). The Yixian taxa provide the first substantial evidence of pterosaurs from the late Neocomian.

The occurrence of a ctenochasmatine in the mid Lower Cretaceous is not unexpected. The clade is known to have survived until the late Early Cretaceous (Fig. 7) because of the presence of Pterodaustro in the Albian Lagarcito Formation (Chiappe et al. 1998a). Teeth of ctenochasmatines have been reported from the basal Cretaceous (Berriasian) of Japan (Hiroshige et al. 2000), but, if correctly identified, Eosipterus currently represents the youngest record for this clade in Eurasia.

The presence of an anurognathid seems, at first glance, to be rather surprising, particularly as it indicates that non-pterodactyloids, long thought to have become extinct at the end of the Jurassic (e.g. Padian 1998) actually persisted into the Early Cretaceous. Until now, anurognathids had only been reported from the Jurassic, although some cladistic analyses (e.g. Unwin 1995) imply that the clade first appeared in the Late Triassic (Fig. 7). Anurognathids have a very patchy fossil record, however, which is almost certainly directly related to their occupation of continental habitats. A range extension of 20 million years is not, therefore, so surprising, especially as this is the first Neocomian locality to produce well preserved, reasonably complete, associated remains of small pterosaurs. Combining this new evidence for the fossil record of anurognathids with the predicted range of the clade based on cladistic analysis, suggests that this clade may have persisted for more than 80 million years. Moreover, the remarkable similarity of Batrachognathus, Anurognathus and Dendrorhynchoides suggests that there was little modification of anurognathid skeletal anatomy over an interval of at least 25 million years.

There are a number of possible explanations for the apparent absence of non-pterodactyloids from the Lower Cretaceous:

(1) Partial extinction. The apparent extinction may be in some part real, in that perhaps only anurognathids persisted into the Lower Cretaceous while the other two main Late Jurassic non-pterodactyloid lineages, the rhamphorhynchines and the scaphognathines, had become extinct by the end of the Jurassic.

(2) Taphonomic bias. Deposits such as the Solnhofen Limestone, that yield wcll preserved associated remains of small vertebrates and that have also been intensively exploited are 
rare in the Neocomian. The Yixian Formation and associated units form the first example from this interval that can be considered, in taphonomic respects and sheer numbers of fossils recovered, as comparable to the Solnhofen Limestone. That they have yielded a non-pterodactyloid only serves to emphasise the patchiness of the pterosaur fossil record.

(3) Taxonomic and systematic biases. Anurognathids must have been present in the Berriasian-Hauterivian interval, and other clades of non-pterodactyloids may also have existed at this time, but the majority of remains recovered from the Neocomian, so far, are highly fragmentary (Tab. 1). Few isolated bones can be reliably identified as non-pterodactyloid (exceptions are the maxilla, caudal vertebrae, wing-metacarpal and [in rhamphorhynchines] the wing-phalanges) while other remains, even though they might be non-pterodactyloid, may have been assigned to the Pterodactyloidea on the grounds that non-pterodactyloids are "known" to have become extinct at the end of the Jurassic. Thus fossil remains of non-pterodactyloids may already be present in museum collections, but remain unidentified and perhaps unidentifiable.

Luo (1999) has suggested, on the basis of the occurrence in the Yixian Formation of "rhamphorhynchoid" pterosaurs, compsognathid theropod dinosaurs and primitive mammals, that, in the Early Cretaceous, eastern Asia was a refugium for typically Late Jurassic taxa. This idea has been challenged by Manabe et al. (2000) who argue that new fossil finds suggest that the historical biogeography of this region may have been much more complex than previously thought.

Three aspects of the Yixian pterosaur assemblage also contradict the idea of a refugium. First, as noted above, pterosaurs have a patchy and highly biased fossil record. In their case, arguments for a refugium depend upon the absence of fossils, rather than a dense, continuous, and widely distributed sequence of fossils that show, for example, that in the Early Cretaceous relict forms similar to those from the Late Jurassic are restricted to eastern Asia. Second, while Dendrorhynchoides could be argued to be a relict, Eosipterus could not, because other ctenochasmatoids are known from the Lower Cretaceous and have also been reported from outside Asia (Tab. 1). Third, pterosaurs were highly mo- bile, with few if any restrictions on their dispersal, thus it seems unlikely that they would have been confined to refugia.

\section{Pterosaurs as stratigraphic indicators}

Ji \& Ji (1998) and Ji Shu'an et al. (1999) argued that the similarity of the Yixian pterosaurs to the Late Jurassic forms Pterodactylus and Rhamphorhynchus supported the idea that the Yixian Formation is Late Jurassic in age.

There are two difficulties with this argument. The first concerns the identity of the Yixian pterosaurs. We have shown, above, that Dendrorhynchoides is an anurognathid pterosaur. This clade is certainly known from the Late Jurassic and probably originated in the Late Triassic. Thus the presence of this taxon in the Yixian Formation could be taken as evidence in favour of a Jurassic rather than Cretaceous age for this unit. By contrast, Eosipterus probably belongs to the Ctenochasmatoidea (a clade that is known to have existed in the Late Jurassic and Early Cretaceous), and appears to be most closely related to Pterodaustro, a form that is currently known only from the Albian (Chiappe 1998a). Thus, if pterosaurs were to be employed for dating purposes, the Yixian taxa could be used to support either a Late Jurassic or an Early Cretaceous age.

The second difficulty is more general and more serious. Fossils selected as candidates for dating purposes must satisfy three basic criteria. They should be: (1) distinct and easily recognisable; (2) common, and with a wide horizontal distribution; and (3) have a clear, well defined and short vertical range (Clarkson 1986). Pterosaurs do not satisfy any of these criteria. Unless critical parts of the skeletal anatomy are preserved (specifically the skull, or at least a substantial portion of the jaws and dentition) it is difficult to assign specimens to particular genera or species. The Yixian pterosaurs provide a good example of this - the skull of Dendrorhynchoides clearly demonstrates that it is an anurognathid, while the headless remains of Eosipterus are difficult to assign, even at the superfamily level. The pterosaur fossil record is dominated by fragmentary remains few of which can be assigned to a particular taxon. Moreover, fossil remains of pterosaurs are rare and, with a few exceptions, most genera and species are known only from a single locality (cf. Wellnhofer 1978, 1991a). At present, it is doubtful whether a reliable strati- 
graphic range can be specified for any clade. irrespective of its rank. The only conclusion that can be drawn from these observations is that pterosaurs are highly unreliable as indicators of stratigraphic age and it seems unlikely that this situation will improve in the near future.

\section{Acknowledgements}

We are very grateful to Jeff Hecht for providing an original copy of the USA Today article, Oliver Rauhut for help with translations and to Elke Siebert for assistance with the figures. Dave Martill kindly provided information on the age of material from the Isle of Wight. Work by LJ was supported by the Chinese Academy of Sciences and the National Science Foundation. DMU thanks the Royal Socicty (UK) for supporting early stages of the work reported here and the staff of the Institut für Paläontologie. Museum für Naturkunde, Berlin for all their help and assistance. We are very grateful to Paul Barrett. Chris Bennett. Mike Benton. Don Henderson, Dave Martill and Peter Wellnhofer for their constructive criticism of earlier versions of this paper and to Gloria Arratia for her editorial work on the MS.

\section{References}

Bakhurina. N. N. 1982. [A pterodactyl from the Lower Cretaceous of Mongolia]. - Palaeontologicheskii Zhurnal (1982) 4: 104-108. [In Russian].

- 1983. [Early Cretaceous pterosaur localities in western Mongolia]. - Transactions of the Joint Soviet-Mongolian Palaeontological Expedition 24: 126-129. [In Russian].

- 1984. [On the discovery of numerous remains of pterosaurs in the Early Cretaceous locality of Tatal, western Mongolia]. - Bulletin of the Moscow Society for the study of Natural History, Geological Section 59: 130. [In Russian].

- 1986. [Flying reptiles]. - Priroda (1986) 7: 27-36. [In Russian],

- 1988. [On the first rhamphorhynchoid from Asia: Batrachognathus volans Riabinin 1948. from Upper Jurassic beds of Karatau]. - Bulletin of the Moscow Society for the study of Natural History. Geological Section 63: 132 [In Russian].

- 1993. Early Cretaceous pterosaurs from western Mongolia and the evolutionary history of the Dsungaripteroidea. - Journal of Vertebrate Paleontology 13 (Supplement to 3): $24 \mathrm{~A}$.

Bakhurina. N. N. \& Unwin. D. M. 1995. A survey of pterosaurs from the Jurassic and Cretaceous of the former Soviet Union and Mongolia. - Historical Biology 10 197-245.

- 1996. Pterosaurs from continental environments. - Journal of Vertebrate Paleontology 16 (Supplement to 3): 20A

Barrett. P. M. 2000. Evolutionary consequences of dating the Yixian Formation. - Trends in Evolution and Ecology 15: 99-103.

Bazhanov, V. C. \& Yeremin. A. V. 1977. [The first discovery of remains of reptiles in the Cretaceous beds of the Tambov district]. In Darevsky. I. S. (ed.). Problems of Herpetology: 20-21. Herpetology 4 (1977). Leningrad: Nauka Press. [In Russian].

Bell. C. M. \& Padian. K. 1995. Pterosaur fossils from the Cretaceous of Chile: evidence for a pterosaur colony on an inland desert plain. - Geological Magazine 132 $31-38$.
Bennett. S. C. 1989. A pteranodontid pterosaur from the Early Cretaceous of Peru, with comments on the relationships of Cretaceous pterosaurs. - Journal of Paleontology 63: $669-677$.

- 1994. Taxonomy and systematics of the Late Cretaceous pterosaur Pteranodon (Pterosauria, Pterodactyloidea). Occasional Papers of the Natural History Museum, The University of Kansas Lawrence, Kansas 169: 1-70.

- 1995. A statistical study of Rhamphorhynchus from the Solnhofen Limestone of Germany - year-classes of a single large species. - Journal of Paleontology 69: 569-580.

- 1996. Year-classes of pterosaurs from the Solnhofen Limestone of Germany: taxonomic and systematic implications. - Journal of Vertebrate Paleontology 16: 432-444.

- 1997. Terrestrial locomotion of pterosaurs: a reconstruction based on Pteraichnus trackways. - Journal of Vertebrate Paleontology 17: 104-113.

Benton, M. J. 1993. Reptiles. In Benton, M. J. (ed.). The Fossil Record 2: 681-715, Chapman and Hall, London.

Benton. M. J. Bouaziz. S., Buffetaut, E., Martill, D., Ouaja, M. Soussi. M. \& Trueman, C. 2000. Dinosaurs and other fossil vertebrates from fluvial deposits in the Lower Cretaceous of southern Tunisia. - Palaeogeography, Palaeoclimatology. Palaeoecology 157: 227-246.

Benton. M. J., Cook, E., Grigorescu, D., Popa, E. \& Tallódi, E. 1997. Dinosaurs and other tetrapods in an Early Cretaceous bauxite-filled fissure, northwestern Romania. Palaeogeography, Palaeoclimatology, Palaeoecology 130: 275-292.

Bonaparte, J. F. 1970. Pterodaustro guinazui gen. et sp. nov. pterosaurio de la Formación Lagarcito, Provincia de San Luis. Argentina y su significado en la geología regional (Pterodactylidae). - Acta Geológica Lilloana 10: 207-226.

Bonaparte. J. F. \& Sánchez, T. M. 1975. Restos de un pterosaurio. Puntanipterus globosus de la Formación La Cruz, Provincia de San Luis, Argentina. - Acta 1 Congresso Argentino Palcontología J Biostratigrafía 2: 105-113.

Brinkman. D. B. \& Peng Jiang-Hua 1993. Ordosemys leios, n. gen.. n. sp. a new turtle from the Early Cretaceous of the Ordos Basin. Inner Mongolia. - Canadian Journal of Earth Sciences 30: 2128-2138.

Buffetaut. E.. Dubus, B. \& Mazin, J.-M. 1989. Une vertébre de pterosaure (Reptilia: Archosauria) dans L'Albien de LAube (France). - Bulletin annuel de la Association Geologique Auboise 11: 3-8.

Buffetaut. E. \& Wellnhofer, P. 1983. Un reste de Ptérosaurien dans l'Hauterivien (Crétacé inférieur) de la HauteMarne. - Bulletin de la Société géologique de France 25 $111-115$

Cabral-Perdomo. M. A. \& Applegate, S. P. 1994. Pterosaurs from the Tlayúa quarries near Tepexi de Rodríguez, Central Mexico and its palaeoecological significance. - Journal of Vertebrate Paleontology 14 (Supplement to 3): 19A.

Calvo. J. O. 1999. Dinosaurs and other vertebrates of the Lake Ezequiel Ramos Mexia Area, Neuquén - Patagonia. Argentina. In Tomida, Y., Rich, T. H. \& VickersRich. P. (eds). Proceedings of the Second Gondwanan Dinosaur Symposium. National Science Museum Tokyo: 13-45. National Science Museum Monographs 15.

Calvo. J. O. \& Moratalla, J. J. 1998. First record of pterosaur tracks in Southern Continents. - III Encuentro Argentino de Icnología y I Reunión de Icnología del Mercosur. Resúmenes. Mar del Plata 1998: 1-8.

Campos. D. de A. \& Kellner, A. W. A. 1985. Um novo exemplar de Anhanguera blittersdorffi (Reptilia, Pterosauria) da formação Santana, Cretáceo Inferior do Nordeste do Brasil. - Boletim de Resumos, 9 Congresso Brasileiro de Paleontologia: 13.

- 1997. Short note on the first occurrence of Tapejaridae in the Crato Member (Aptian), Santana Formation, Araripe Basin. Northeast Brazil. - Anais da Academia Brasileira de Ciências 69: 83-87. 
Canudo, J. I., Amo, O., Cuenca Bescós, G., Meléndez, A., Ruiz-Omeñaca, J. I. \& Soria, A. R. 1997. Los vertebrados del Titónico-Barremiense de Galve (Terual, España). Cuadernos de Geologia Ibérica 23: 209-241.

Casamiquela, R. M. \& Chong Díaz, G. 1978. La presencia de Pterodaustro Bonaparte (Pterodactyloidea), del Neojurasico (?) de la Argentina, en los Andes del norte de Chile. - Acta del Segundo Congreso Argentino de Paleontología y Bioestratigrafía y Primer congreso Latinamericano de Paleontología 1: 201-209.

Chen Peiji 1988. Distribution and migration of Jehol fauna with reference to non-marine Jurassic-Cretaceous boundary in China. - Acta Palaeontologica Sinica 27: 659-683. [In Chinese].

Chiappe, L. M., Ji Shu'an, Ji Qiang \& Norell, M. A. 1999. Anatomy and systematics of the Confuciusornithidae (Theropoda: Aves) from the Late Mesozoic of northeastern China. - Bulletin of the American Museum of Natural History 242: 1-89.

Chiappe, L. M., Rivarola, D., Cione, A., Fregenal-Martínez, M., Buscalioni, A. D., Sozzi, H., Buatois, L., Gallego, O., Romero, E., Lopez-Arbarello, A., McGehee, S., Marsicano, C., Adamonis, S., Laza, J., Ortega, F. \& Dilorio, O. 1995. Inland biota from a Lower Cretaceous Lagerstätte of Central Argentina. In 2nd International Symposium on Lithographic Limestones, Lleida-Cuenca, Spain: 57-60, Ediciones de la Universidad Autónoma de Madrid.

Chiappe, L. M., Rivarola, D., Cione, A., Fregenal-Martínez, M., Sozzi, H., Buatois, L., Gallego, O., Laza, J., Romero, E., Lopez-Arbarello, A., Buscalioni, A. D., Marsicano, C., Adamonis, S., Ortega, F., McGehee, S. \& Dilorio, O. 1998a. Biotic association and palaeoenvironmental reconstruction of the 'loma del Pterodaustro' fossil site (Early Cretaceous, Argentina). - Geobios 31: 349-369.

Chiappe, L. M., Rivarola, D., Romero, E., Davila, S. \& Codorniu, L. 1998b. Recent advances in the palaeontology of the Lower Cretaceous Lagarcito Formation (Parque Nacional Sierra de las Quijadas, San Luis, Argentina). In Lucas, S. G., Kirkland, J. I. \& Estep, J. W. (eds). Lower and Middle Cretaceous Terrestrial Ecosystems. New Mexico Museum of Natural History and Science, Bulletin 14: 187-192.

Clarkson, E. N. K. 1986 Invertebrate Palaentology and Evolution. 382 pp., Allen \& Unwin, London.

Döderlein, L. 1923. Anurognathus Ammoni ein neuer Flugsaurier. - Sitzungsberichte der Bayerischen Akademie der Wissenschaften, mathematisch-naturwissenschaftliche Abteilung: 117-164.

Dong Zhiming 1992. Dinosaurian faunas of China. 188 pp., China Ocean Press, Beijing.

- 1993. A new species of stegosaur (Dinosauria) from the Ordos Basin, Inner Mongolia, People's Republic of China. - Canadian Journal of Earth Sciences 30: 2174-2176.

Ensom, P. C. 1984. Purbeckopus pentadactylus Delair. - Proceedings of the Dorset Natural History and Archaeological Society 105: 166

Evans, S. E., Manabe, M., Cook, E., Hirayama, R., Isaji, S., Nicholas, C., Unwin, D. M. \& Yabumoto, Y. 1998. An Early Cretaceous assemblage from Gifu Prefecture, Japan. In Lucas, S. G., Kirkland, J. I. \& Estep, J. W. (eds). Lower and Middle Cretaceous Terrestrial Ecosystems. New Mexico Museum of Natural History and Science, Bulletin 14: 183-186.

Fregenal-Martínez, M. A. \& Moratalla, J. J. 1995. Paleoichnology. In Meléndez, M. (ed.). Las Hoyas. A lacustrine Konservat-Lagerstätte, Cuenca, Spain: 71-75. Field Trip Guide Book, 2nd International Symposium on Lithographic Limestones, Cuenca, Spain. 1995.

Frey, E. \& Martill, D. M. 1994. A new pterosaur from the Crato Formation (Lower Cretaceous, Aptian) of Brazil. Neues Jahrbuch für Geologie und Paläontologie Abhandlung 194: $379-412$.
Friend, T. 2000. The 'missing link' that wasn't. - USA Today, Tuesday February 1: $1-2$.

Fuentes Vidarte, C. \& Meijide Calvo, M. 1996. Restos de Pterosaurios en el 'Weald' de Soria (España). - Studia Geologica Salamanticensa 32: 15-22.

Galton, P. M. 1994. Notes on Dinosauria and Pterodactylia from the Cretaceous of Portugal. - Neues Jahrbuch Geologie und Paläontologie Abhandlung 194: 253-267.

Gilmore, C. W. 1928. A new pterosaurian reptile from the marine Cretaceous of Oregon. - Proceedings of the United States National Museum 73: 1-5.

Henderson, D. \& Unwin, D. M. 1999. Mathematical and computational modelling of a walking pterosaur. - Journal of Vertebrate Paleontology, 19 (Supplement to 3): $50 \mathrm{~A}$.

Hiroshige, M., Manabe, M. \& Unwin, D. M. 2000. Palaeontology of the Lower Cretaceous Kuwajima Formation of Shiramine, Ishikawa Prefecture, Japan (submitted).

Hooley, R. W. 1913. On the skeleton of Ornithodesmus latidens from the Wealden of Atherfield (Isle of White). Quarterly Journal Geological Society, London 69: $372-422$.

- 1914. On the ornithosaurian genus Ornithocheirus, with a review of the specimens of the Cambridge Greensand in the Sedgwick Museum. - Annals and Magazine of Natural History 8 (13): 529-557.

Howse, S. C. B. 1986. On the cervical vertebrae of the Pterodactyloidea (Reptilia: Archosauria). - Zoological Journal of the Linnean Society, 88: 307-328.

Howse, S. C. B. \& Milner, A. R. 1993. Ornithodesmus - a maniraptoran theropod dinosaur from the Lower Cretaceous of the Isle of Wight, England. - Palaeontology 36: $425-437$.

- 1995. The pterodactyloids from the Purbeck Limestone Formation of Dorset. - Bulletin of the Natural History Museum, London (Geology) 51: 73-88.

Ji Qiang, Ji Shu'an, Ren Dong, Lu Liwu, Fang Xiaosi \& Guo Ziguang 1999. On the sequence and age of the protobirdbearing deposits in the Sihetun-Jianshangou area, Beipiao, western Liaoning. In Professional Papers of Stratigraphy and Paleontology 27: 74-80.

Ji Shu'an \& Ji Oiang 1997. Discovery of a new pterosaur in western Liaoning, China. - Acta Geologica Sinicia 71(1): 1-6. [In Chinese].

- 1998. A new fossil pterosaur (Rhamphorhynchoidea) from Liaoning. - Jiangsu Geology 22(4): 199-206. [In Chinese].

Ji Shu'an, Ji Qiang \& Padian, K. 1999. Biostratigraphy of new pterosaurs from China. - Nature 398: 573-574.

Jin Fan 1996. New advances in the Late Mesozoic stratigraphic research of western Liaoning, China. - Vertebrata PalAsiatica: 34 (1): 102-122. [In Chinese].

Jin Fan, Zhang Jiangyong \& Zhou Zhonghe 1995. Late Mesozoic fish fauna from western Liaoning, China. - Vertebrata PalAsiatica 33(3): 169-193. [In Chinese].

Jurcsák, T. \& Popa E. 1983. La faune de dinosauriens du Bihor (Roumanie). In Buffetaut, E., Mazin, J.-M. \& Salmon, E. (eds). Actes du Symposium Paléontologique G. Cuvier, Montbéliard: 325-335. Ville de Montbéliard.

Kaup, J. J. 1834. Versuch einer Eintheilung der Saugethiere in 6 Stämme und der Amphibien in 6 Ordnungen. - Isis 3: $311-315$.

Kellner, A. W. A. 1984. Ocorrência de uma mandíbula de pterosauria (Brasileodactylus araripensis, nov. gen.; nov. sp.) na formação Santana, Cretáceo da chapada do Araripe, Ceará, Brasil. - 33 Congresso Brasileiro de Geologia, Anais 2: 578-590.

1989. A new edentate pterosaur of the Lower Cretaceous from the Araripe Basin, Northeast Brazil. - Anais da Academia Brasileira de Ciências 61(4): 439-446.

- 1997. Reinterpretation of a remarkably well preserved pterosaur soft tissue from the Early Cretaceous of Brazil - Journal of Vertebrate Paleontology 16: 718-722. 
Kellner. A. W. A. \& Campos, D. de A. 1988. Sobre un novo pterossauro com crista sagital da Bacia do Araripe. Cretáceo Inferior do Nordeste do Brasil. (Pterosauria. Tupuxuara, Cretaceo. Brasil). - Anais da Academia Brasileira de Ciências 60(4): 459-469.

- 1994. A new species of Tupuxuara (Pterosauria. Tapejaridae) from the Early Cretaceous of Brazil. - Anais da Academia Brasileira de Ciências 66(4): $467-473$.

Kranz. P. M. 1998. Mostly dinosaurs: A review of the vertebrates of the Potomac Group (Aptian Arundel Formation), USA. In Lucas. S. G.. Kirkland. J. I. \& Estep. J. W. (eds). Lower and Middle Cretaceous Terrestrial Ecosystems. New Mexico Museum of Natural History and Science. Bulletin 14: 235-238

Krebs. B. 1985. Theria (Mammalia) aus der Unterkreide von Galve (Provinz Teruel. Spanien). - Berliner Geowissenschaftliche Abhandlungen 60: 29-48.

Kuhn. O. 1937. Die fossilen Reptilien. 12lpp. Borntraeger. Berlin.

- 1967. Die fossile Wirbeltierklasse Pterosauria. 52 pp. Oeben, Krailing bei München.

Langston, W. Jr. 1974. Non-mammalian Comanchean tetrapods. - Geoscience and Man 8: 77-102.

Lee. Y. N. 1994. The early Cretaceous pterodactyloid pterosaur Coloborhynchus from North America. - Palaeontology 37: $755-763$.

Leonardi, G. \& Borgomanero. G. 1985. Cearadactvlus atrox nov. gen.. nov. sp.: novo Pterosauria (Pterodactyloidea) da Chapada do Araripe. Ceara. Brasil. - Coletânea de Trabalhos Paleontológicos. Série Geologia. Brasilia: 75-80.

Lin Qibin 1998. Cretaceous insects of China. - Cretaceous Research 15: $305-316$.

Lockley, M. G., Logue. T. J. Moratalla. J. J. Hunt. A. P. Schultz. R. J. \& Robinson. J. W. 1995. The fossil trackway Pteraichnus is pterosaurian. not crocodilian: implications for the global distribution of pterosaur tracks - Ichnos 4: $7-20$.

Lü Junchang \& Wang Xiaolin 2000 . The first report of soft tissue impressions of pterodactyloid pterosaurs from the western part of Liaoning province. China. - Chinese Science Bulletin (in press).

Luo Zhexi 1999. - A refugium for relicts. - Nature 400: 23 - 25.

Manabe. M. Barrett. P. M. \& Isaji. S. 2000. A refugium for relicts? - Nature 404: 953

Mantell. G. A. 1827. Illustrations of the geology of Sussex. London: Lupton Relfe.

Martill. D. M. \& Frey. E. 1998. A new pterosaur lagerstätte in N.E. Brazil (Crato Formation: Aptian. Lower Cretaceous): preliminary observations. - Orvctos 1: 79-85.

- 1999. A possible azhdarchid pterosaur from the Crato Formation (Early Cretaceous. Aptian) of northeast Brazil. - Geologie en Mijnbouw 78: 315-318.

Martill, D. M., Frey, E.. Chong Diaz. G. \& Bell. C. M. 2000 Reinterpretation of a Chilean pterosaur and the occur rence of Dsungaripteridae in South America. - Geological Magazine 137: 19-25.

Martill, D. M. \& Unwin. D. M. 1989. Exceptionally well preserved pterosaur wing membrane from the Cretaceous of Brazil. - Nature 340: $138-139$.

Martill, D. M.. Wilby. P. \& Unwin. D. M. 1990. Stripes on a pterosaur wing. - Nature 346: 116.

Meijide Calvo. M. \& Fuentes Vidarte. C. 1999. Huellas de Pterosaurios en el Weald de Soria (España). I Jornadas Internacionales sobre Paleontología de dinosaurios y su entorno, Resumen. Unpaginated.

Meléndez. M. N. 1995. (ed.). Las Hovas. A lacustrine Konservat-Lagerstätte Cuenca. Spain. II International Symposium on Lithographic Limestones: $89 \mathrm{pp}$. Field trip guide book. Universidad Complutense de Madrid.

Molnar. R. E. 1987. A pterosaur pelvis from western Queensland, Australia. - Alcheringa 11: 87-94.

Molnar. R. E. \& Thulborn. R. A. 1980. First pterosaur from Australia. - Nature 288: $361-363$
Montanelli. S. B. 1987. Presencia de Pterosauria (Reptilia) en la Formación La Amarga (Hauteriviano-Barremiano), Neuquén. Argentina. - Ameghiniana 24: 109-113.

Moratalla. J. J. 1993. Restos indirectos de dinosaurios del registro español: Paleoicnología de la Cuenca de Cameros Jurassico superior-Cretácico inferior y Paleoecología del Cretácico superior. PhD thesis. Universidad Autónoma de Madrid.

Moratalla. J. J.. Lockley. M. G., Buscalioni, A. D., FregenalMartínez. M. A.. Meléndez. N., Ortega, F., Pérez-Moreno, P. Pérez-Asensio, E.. Sanz. J. L. \& Schultz, R. J. 1995. A preliminary note on the first tetrapod trackways from the Lithographic Limestones of Las Hoyas (Lower Cretaccous. Cuenca. Spain). - Geobios 28: 777-782.

Murr: P. A.. Winkler, D. A. \& Jacobs, L. L. 1991. An azhdarchid pterosaur humerus from the Lower Cretaceous Glen Rose Formation of Texas. - Journal of Paleontology $65: 167-170$.

Nesov. L. A. 1990. [Flying reptiles of the Jurassic and Cretaceous of the USSR and the significance of their remains for the reconstruction of paleogeographic conditions]. Bulletin of Leningrad University, Series 7, Geology and Geography 1990. 4 (28): 3-10. [In Russian].

Nopcsa. F. 1928. The Genera of Reptiles. - Palaeobiologica 1: $163-188$.

Owen. R. 1859. Supplement (No. I) to the monograph on the Fossil Reptilia of the Cretaceous Formations. - Monographs of the Palacontographical Society: 1-19.

- 1861. Supplement (No. III) to the Monograph on the Fossil Reptilia of the Cretaceous Formations. - Monographs of the Palaeontographical Society: $1-19$.

1874. A Monograph on the Fossil Reptilia of the Mesozoic Formations. - Monographs of the Palaeontographical Society: 1-14.

Padian. K. 1980. Note of a new species of pterosaur (Reptilia: Pterosauria) from the Norian (Upper Triassic) of Endenna. Italy. - Rivista del Museo Civico di Scienze Naturali "Enrico Caffi" 2: 119-127.

- 1984. A large pterodactyloid pterosaur from the Two Medicine Formation (Campanian) of Montana. - Journal of Vertebrate Palaeontology 4: 516-524.

- 1988. The flight of pterosaurs. - Natural History 97 (12): 58-65

1998. Pterosaurs and ?avians from the Morrison Formation (Late Jurassic. Western U.S.). - Modern Geology 23: $57-68$.

Plieninger, F. 1901. Beiträge zur Kenntnis der Flugsaurier. Palaeontographica 48: 65-90

Riabinin. A. N. 1948. [Remarks on a flying reptile from the Jurassic of the Karatau]. - Transactions of the Palaeontological Institute 15 (1): 86-93. [In Russian].

Rich. T. H. V. \& Rich. P. V. 1989. Polar dinosaurs and biotas of the Early Cretaceous of southeastern Australia. - National Geographic Research 5 (1): 15-53.

Ridley. M. 1986. Evolution and classification. 201 pp., Longman. London and New York

Ruiz-Omeñaca, J. I. Canudo. J. I. \& Cuenca-Bescós, V. G. 1998. Primeros restos de reptiles voladores (Pterosauria: Pterodactyloidea) en el Barremiense superior (Cretácico inferior) de Vallipón (Castellote, Teruel). - Mas de la Matas 17: $225-249$

Russell. D. A. \& Dong Zhiming 1993. A nearly complete skeleton of a new troodontid dinosaur from the Early Cretaceous of the Ordos Basin. Inner Mongolia, People's Republic of China. - Canadian Journal of Earth Sciences 30: $2163-2173$.

Sanchez. T. M. 1973. Redescripcion del cráneo y mandíbulas de Pterodaustro guinazui Bonaparte (Pterodactyloidea, Pterodaustriidae). - Ameghiniana 10: 313-325.

Sanz. J. L.. Buscalioni. A. D.. Moratalla, J. J., Francés, V. \& Antón. M. 1990. Los reptiles mesozoicos del registro español. - Monografías del Museo Nacional de Ciencias Naturales CSIC 2: $1-80$ 
Sauvage, H.-E. 1882. Recherches sur les reptiles trouvés dans le Gault de l'Est du bassin de Paris. - Memoires Sociéte Géologique de France 3 (2): 4.

Seeley, H. G. 1869. Index to the fossil remains of Aves, Ornithosauria and Reptilia. 143 pp., Deighton, Bell \& Co., Cambridge.

- 1870. The Ornithosauria: an elementary study of the bones of pterodactyles, made from fossil remains found in the Cambridge Greensand, and arranged in the Woodwardian Museum of the University of Cambridge. 135 pp., Deighton, Bell \& Co., Cambridge.

- 1871. Additional evidence of the structure of the head in ornithosaurs from the Cambridge Upper Greensand being a supplement to "The Ornithosauria". - Annals and Magazine of Natural History 7 (37): 20-36.

- 1881. On evidence of two ornithosaurians referable to the genus Ornithocheirus, from the Upper Greensand of Cambridge, preserved in the collection of W. Reed, Esq., F. G. S. - Geological Magazine 8: 13-20.

- 1891. On the shoulder girdle in Cretaceous Ornithosauria. - Annals and Magazine of Natural History 6 (7): $438-445$.

1901. Dragons of the air. An account of extinct flying reptiles. 239 pp., Methuen, London.

Sereno, P. C., Beck, A. L., Dutheil, D. B., Gado, B., Larsson, H. C. E., Lyon, G. H., Marcot, J. D., Rauhut, O. W. M., Sadleir, R. W., Sidor, C. A., Varricchio, D. D., Wilson, G. P. \& Wilson, J. A. 1998. A long-snouted predatory dinosaur from Africa and the evolution of the spinosaurids. Science 282: 1298-1302.

Sharov, A. G. 1971. [New flying reptiles from the Mesozoic of Kazakhstan and Kirghizia]. - Transactions of the Palaeontological Institute 130: 104-113. [In Russian].

Sigogneau-Russell, D., Evans, S. E., Levine, J. F. \& Russell, D. A. 1998. The Early Cretaceous microvertebrate locality of Anoual, Morocco: A glimpse at the small vertebrate assemblages of Africa. In Lucas, S. G., Kirkland, J. I. \& Estep, J. W. (eds). Lower and Middle Cretaceous Terrestrial Ecosystems. New Mexico Museum of Natural History and Science, Bulletin 14: 177-181.

Stricklin, F. L. Jr. \& Amsbury, D. L. 1974. Depositional environment on a low-relief carbonate shelf, middle Glen Rose Limestone, central Texas. - Geoscience and Man 8 : $53-66$

Swisher, C.C. III., Wang Yuanqing, Wang Xiaolin, Xu Xing \& Wang Yuan 1999. Cretaceous age for the feathered dinosaurs of Liaoning, China. - Nature 400: 58-61.

Taylor, D. W. \& Hickey, L. J. 1996. (eds). Flowering plant origin, evolution and phylogeny. 403 pp., Chapman and Hall, London.

Tyne, J. V. \& Berger, A. J. 1976. Fundamentals of Ornithology. 2nd Edition. 808 pp., Wiley and sons, New York.

Unwin, D. M. 1995. Preliminary results of a phylogenetic analysis of the Pterosauria (Diapsida: Archosauria). In Sun Ailing \& Wang Yuanqing (eds). Sixth Symposium on Mesozoic Terrestrial Ecosystems and Biota. Short Papers: 69-72, China Ocean Press, Beijing.

- 1997. Pterosaur tracks and the terrestrial ability of pterosaurs. - Lethaia 29: 373-386.

- 1999. Pterosaurs: back to the traditional model? - Trends in Evolution and Ecology 14: 263-268.

- 2000. The biology of pterosaurs. - In Encyclopedia of Life Sciences: Macmillan, London. (In press).

Unwin, D. M. \& Bakhurina, N. N. 2000. Pterosaurs from Russia, Middle Asia and Mongolia. In Benton, M. J., Shiskin, M., Unwin, D. M. \& Kurochkin, E., (eds). The Age of Dinosaurs in Russia and Mongolia. Cambridge .University Press. (In press).

Unwin, D. M., Hasegawa, Y., Shimizu, K. \& Manabe, M. 1996. First record of pterosaurs from the Early Cretaceous Tetori Group: a wing-phalange from the Amagodani Formation in Shokawa, Gifu Prefecture, Japan. - Bulletin of the National Science Museum, Tokyo. Series $C$ (Geology and Paleontology) 22: 37-46.

Unwin, D. M. \& Heinrich, W.-D. 1999. On a pterosaur jaw from the Upper Jurassic of Tendaguru (Tanzania). - Mitteilungen aus dem Museum für Naturkunde in Berlin. Geowissenschaftlichen Reihe 2: 121-134.

Unwin, D. M. \& Henderson, D. 1999. Testing the terrestrial ability of pterosaurs with computer-based methods. Journal of Vertebrate Paleontology 19 (Supplement to 3): $81 \mathrm{~A}$.

Unwin, D. M. \& Lü Junchang 1997. On Zhejiangopterus and the relationships of pterodactyloid pterosaurs. - Historical Biology 12: 199-210.

Wang Xiaolin, Wang Yanqing, Jin Fan, Xu Xing, Wang Yuan, Zhang Jiangyong, Zhang Fucheng, Tang Zhilu, Li Chuankui \& Gu Gang 1999. The Sihetun fossil vertebrate assemblage and its geological setting of western Liaoning. China. - Palaeoworld 11: 310-327.

Wang Xiaolin, Wang Yuanqing, Wang Yuan, Xu Xing. Tang Zhilu, Zhang Fucheng, Hu Yaoming, Gu Gang \& Hao Zhaolin 1998. Stratigraphic sequence and vertebrate-bearing beds of the lower part of the Yixian Formation in Sihetun and neighbouring area, western Liaoning. China. - Vertebrata PalAsiatica 36 (2): 81-101. [In Chinese].

Wellnhofer, P. 1970. Die Pterodactyloidea (Pterosauria) der Oberjura Plattenkalke Süddeutschlands. - Abhandlungen der Bayerischen Akademie der Wissenschaften zu München, Mathematisch-Naturwisenschaftlichen Klasse 141: $1-133$.

- 1975a. Die Rhamphorhynchoidea (Pterosauria) der Oberjura-Plattenkalke Süddeutschlands. II. Systematische Beschreibung. - Palaeontographica A 148: 132-186.

- 1975b. Die Rhamphorhynchoidea (Pterosauria) der Oberjura-Plattenkalke Süddeutschlands. III. - Palökologie und Stammesgeschichte. - Palaeontographica A 149: $1-30$.

- 1978. Handbuch der Paläoherpetologie. Teil 19. Pterosauria: 82 pp., Gustav Fischer Verlag, Stuttgart.

- 1985. Neue Pterosaurier aus der Santana Formation (Apt.) der Chapada do Araripe, Brasilien. - Palaeontographica A 187: 105-182.

- 1987. New crested pterosaurs from the lower Cretaceous of Brazil. - Mitteilungen der Bayerischen Staatssammlung für Paläontologie und historische Geologie 27: 175-186.

- 1991a. The Illustrated Encyclopedia of Pterosaurs. 192 pp. Salamander Books, London.

- 1991b. Santana Formation pterosaurs. In Maisey, J. G. (ed.). Santana fossils: an illustrated atlas: $351-370$. T.F.H., Neptune City, New Jersey.

- 1991c. Weitere Pterosaurierfunde aus der Santana-Formation (Apt) der Chapada do Araripe, Brasilien. - Palaeontographica A 215: 43-101.

Wellnhofer, P. \& Kellner, A. W. A. 1991. The skull of Tapejara wellnhoferi Kellner (Reptilia: Pterosauria) from the Lower Cretaceous Santana Formation of the Araripe Basin, Northeastern Brazil. - Mitteilungen der Bayerischen Staatssammlung für Paläontologie und historische Geologie 31: $89-106$.

Wild, R. 1978. Die Flugsaurier (Reptilia, Pterosauria) aus der Oberen Trias von Cene bei Bergamo. - Bolletino Societa Paleontologica Italiana 17 (2): 176-256.

- 1984. A new pterosaur (Reptilia, Pterosauria) from the Upper Triassic (Norian) of Friuli, Italy. - Gortania Atti Museo Friuli Storia Naturale 5: 45-62.

- 1990. Ein Flugsaurierrest (Reptilia, Pterosauria) aus der Unterkreide (Hauterive) von Hannover (Niedersachsen). - Neues Jahrbuch Geologie und Paläontologie Abhandlung 181: $241-254$.

1993. A juvenile specimen of Eudimorphodon ranzii Zambelli (Reptilia, Pterosauria) from the Upper Triassic (Norian) of Bergamo. - Rivista del Museo Civico di Scienze Naturali "Enrico Caffi" 16: 95-120. 
Wright, J. L., Unwin, D. M.. Lockley, M. G. \& Rainforth. E. 1997. Pterosaur tracks from the Purbeck Formation of Dorset, England. - Proceedings of the Geologist's Association 108: $39-48$.

Xu Xing \& Wang Xiaolin 1998. New psittacosaur (Ornithischia, Ceratopsia) occurence from the Yixian Formation of Liaoning. China and its stratigraphical significance. - Vertebrata PalAsiatica 36: 147-158.

Young Chungchien 1958. The dinosaurian remains of Laiyang, Shantung. -- Palaeontologia Sinica 142: 1-138. [In Chinese].
- 1964. On a new pterosaurian from Sinkiang, China. Vertebrata PalAsiatica 8: 221-255.

- 1973. [Wuerho pterosaurs]. - Special Publication of the Institute of Vertebrate Palaeontology and Palaeoanthropology, Academia Sinica 11: 18-34. [In Chinese].

Zangerl, R. \& Denison, R. H. 1950. Discovery of Early Cretaceous mammals and frogs in Texas. - Science 112: 61. 